\title{
Systematics of Water Temperature and Flow at Tantalus Creek During Calendar Year 2005, Norris Geyser Basin, Yellowstone National Park, Wyoming
}

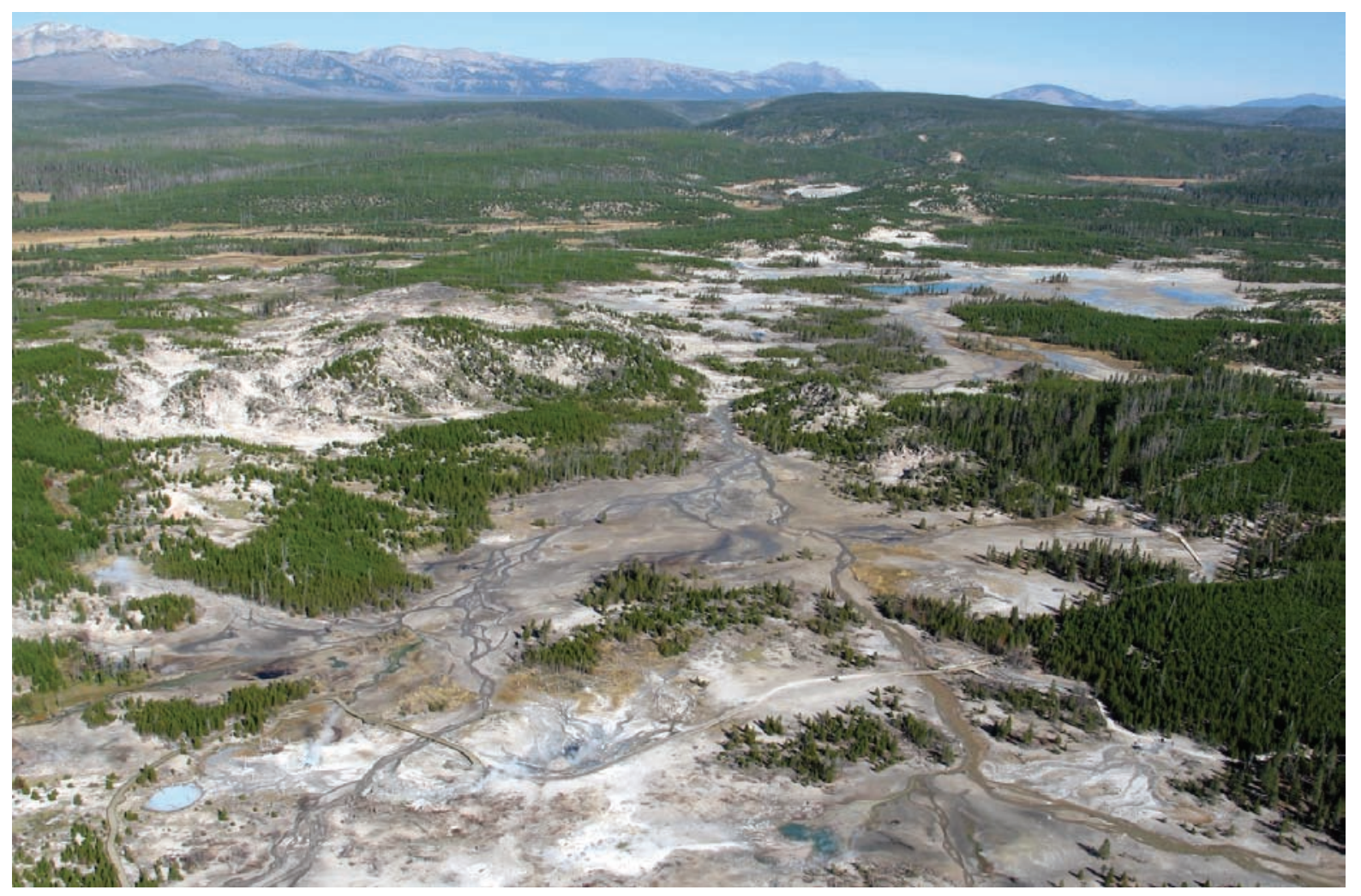

Scientific Investigations Report 2007-5234 


\title{
U.S. Department of the Interior DIRK KEMPTHORNE, Secretary
}

\section{U.S. Geological Survey Mark D. Myers, Director}

\author{
U.S. Geological Survey, Reston, Virginia: 2007
}

This report and any updates to it are available at:

http://pubs.usgs.gov/sir/2007/5234/

For product and ordering information:

World Wide Web: http://www.usgs.gov/pubprod

Telephone: 1-888-ASK-USGS

For more information on the USGS — the Federal source for science about the Earth,

its natural and living resources, natural hazards, and the environment:

World Wide Web: http://www.usgs.gov

Telephone: 1-888-ASK-USGS

Any use of trade, product, or firm names is for descriptive purposes only and does not imply endorsement by the U.S. Government.

Although this report is in the public domain, permission must be secured from the individual copyright owners to reproduce any copyrighted materials contained within this report.

Suggested citation:

Clor, L., Lowenstern, J., Heasler, H, 2007, Systematics of water temperature and flow at Tantalus Creek during calendar year 2005, Norris Geyser Basin, Yellowstone National Park, Wyoming: U.S. Geological Survey Scientific Investigation Report 2007-5234.

Cataloging-in-publication data are on file with the Library of Congress (http://www.loc.gov/).

Produced in the Western Region, Menlo Park, California

Manuscript approved for publication, August 28, 2007

Text edited by James W. Hendley II

Layout by David R. Jones

FRONT COVER - Tantalus Creek collects nearly all the thermal water discharged at the Norris Geyser Basin, pictured below. The bottom of the photo shows tributaries of Tantalus Creek draining the Gray Lakes (left) and Steamboat-EchinusEmerald hydrologic subbasins. Photo taken from a balloon-mounted camera by B. Graham Wall, September 2005. 


\section{Systematics of Water Temperature and Flow at Tantalus Creek During Calendar Year 2005, Norris Geyser Basin, Yellowstone National Park, Wyoming}

By Laura E. Clor, Jacob B. Lowenstern, and Henry P. Heasler

Scientific Investigations Report 2007-5234 


\section{U.S. Department of the Interior DIRK KEMPTHORNE, Secretary}

\section{U.S. Geological Survey \\ Mark D. Myers, Director}

U.S. Geological Survey, Reston, Virginia: 2007

This report and any updates to it are available at:

http://pubs.usgs.gov/sir/2007/5234/

For product and ordering information:

World Wide Web: http://www.usgs.gov/pubprod

Telephone: 1-888-ASK-USGS

For more information on the USGS - the Federal source for science about the Earth,

its natural and living resources, natural hazards, and the environment:

World Wide Web: http://www.usgs.gov

Telephone: 1-888-ASK-USGS

Any use of trade, product, or firm names is for descriptive purposes only and does not imply endorsement by the U.S. Government.

Although this report is in the public domain, permission must be secured from the individual copyright owners to reproduce any copyrighted materials contained within this report.

\section{Suggested citation:}

Clor, Laura E., Lowenstern, Jacob B., Heasler, Henry P., 2007, Systematics of water temperature and flow at Tantalus Creek during calendar-year 2005, Norris Geyser Basin, Yellowstone National Park, Wyoming: U.S. Geological Survey Scientific Investigations Report 2007-5234.

Cataloging-in-publication data are on file with the Library of Congress (http://www.loc.gov/).

Produced in the Western Region, Menlo Park, California

Manuscript approved for publication, October 4, 2007

Text edited by James W. Hendley II

Layout by David R. Jones 


\section{Contents}

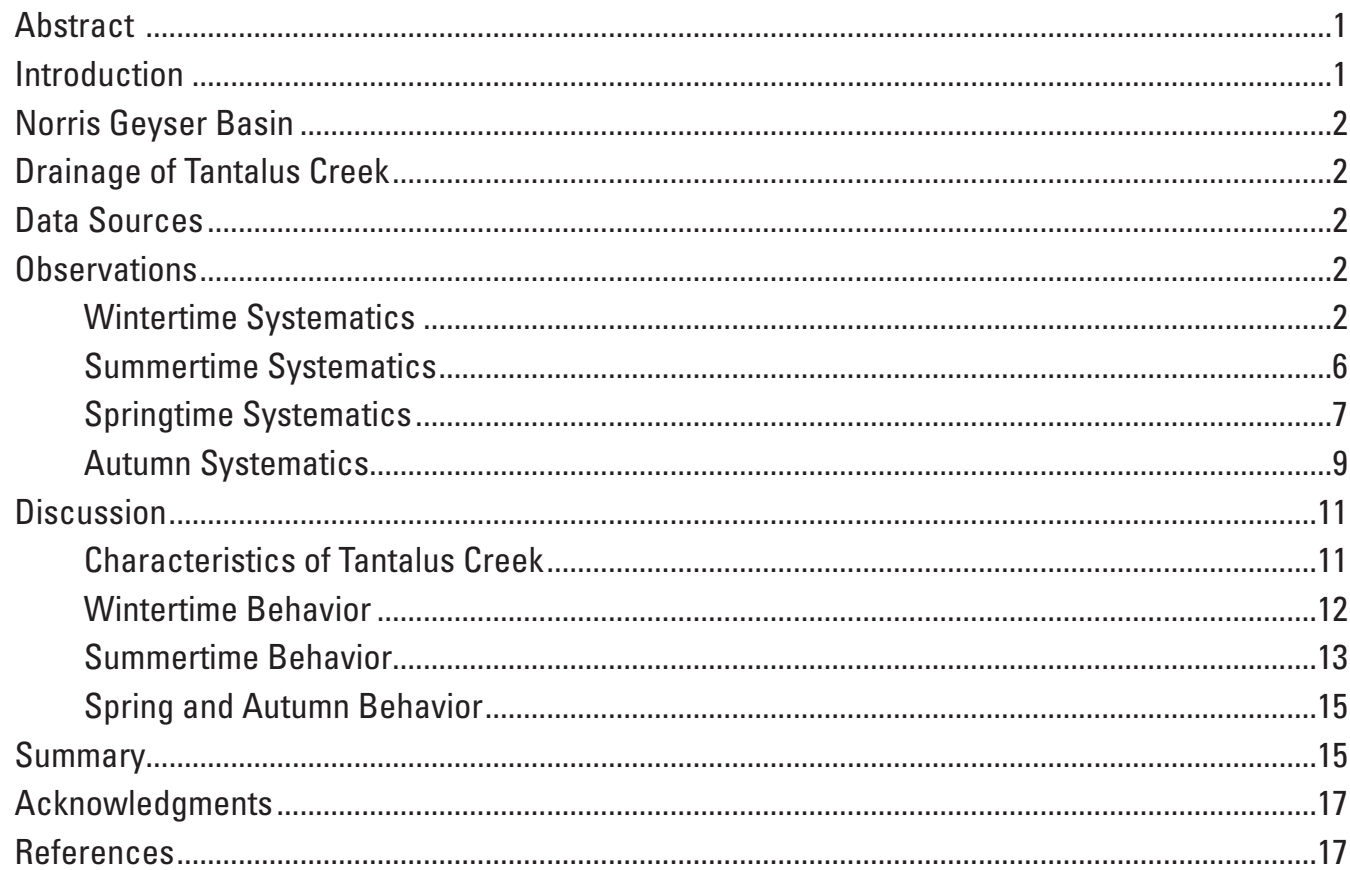

\section{Figures}

1. Area map of Norris Geyser Basin

2. Daily average air temperatures for Norris Geyser Basin from

December 2004 through December 2005, measured at the Norris Museum

3. Air temperature at Norris Museum, and water temperature, stream flow, and precipitation at Tantalus Weir for the week of February 22 to March 1, 2005.

4. Correlations between $(A)$ air and water temperature, $(B)$ air temperature and stream flow, and $(C)$ water temperature and stream flow for the week of February 22 to March 1, 2005

5. Close-up view of data from February 24, 2005, showing air temperature, water temperature, and stream flow

6. Air temperature, water temperature, stream flow, and precipitation for the week of September 1-8, 2005

7. Close-up view of September 2, including the last 8 hours of September 1 and the first 8 hours of September 3

8. Plot of air temperature versus water temperature for the week of September 1-8, 2005 .

9. Air temperature, water temperature, stream flow, and precipitation for the week of August 9-16, 2005.

10. Air temperature, water temperature, stream flow, and precipitation for the 8-day period of March 7-15, 2005

11. Air temperature, water temperature, stream flow, and precipitation for the week of April 17-24, 2005 
12. Air temperature, water temperature, stream flow, and precipitation for the week of October 26 to November 2, 2005

13. Air temperature, water temperature, stream flow, and precipitation for the week of October 12-19, 2005

14. Air temperature, water temperature, stream flow, and precipitation for the week of November 7-14, 2005

15. Air temperature, water temperature, stream flow, and precipitation for the week of November 17-24, 2005

16. Schematic diagram depicting the response of snow cover, and hence ground temperature, in the vicinity of Tantalus Creek to varying winter air temperatures.

17. Comparison of water temperatures of Tantalus Creek at the weir and also the Gibbon River at Madison Junction from February 2005 through January 2006 


\title{
Systematics of Water Temperature and Flow at Tantalus Creek During Calendar Year 2005, Norris Geyser Basin, Yellowstone National Park, Wyoming
}

\author{
By Laura E. Clor, Jacob B. Lowenstern, and Henry P. Heasler
}

\section{Abstract}

We analyze data for stream flow and water temperature from Tantalus Creek in the Norris Geyser Basin and their relationship to air temperature, precipitation, and geyser eruptions during calendar year 2005. The creek is of interest because it is the primary drainage of the Norris Geyser Basin and carries a very high proportion of thermal water derived directly from hot springs. Two separate diurnal patterns emerge - (1) a winter pattern where increases in water temperature and stream flow closely track those of air temperature and (2) a summer pattern where water and air temperature are closely aligned but stream flow declines once water temperature reaches its daily maximum. The winter pattern is present when the daily average temperature consistently drops below $0^{\circ} \mathrm{C}$ whereas the summer pattern is recognizable when the daily average temperature regularly exceeds $0^{\circ} \mathrm{C}$. Spring and fall systematics are much more irregular, although both summer and winter patterns can be discerned occasionally during those seasons. We interpret increases in stream flow associated with the winter pattern to result from addition of locally sourced melt water (both snow and soil-bound ice) that increases in abundance once temperatures increase in the morning. Melting is facilitated by the warm ground temperatures in the geyser basin, which are significantly higher than air temperatures in the winter. The summer pattern appears to be strongly affected by increased evaporation in the afternoon, decreasing flow and cooling the remaining water. Discharge from eruptions at Echinus Geyser are clearly visible as peaks in the hydrograph, and indicate that water from this geyser reach the Tantalus weir in 80 to 90 minutes, reflecting a slug of water that travels about $0.4 \mathrm{~m} \mathrm{~s}^{-1}$.

\section{Introduction}

Streamflow monitoring is an important means for tracking geological activity in hydrothermal areas (Ingebritsen and others, 2001; Hurwitz and others, 2007; Friedman and Norton, in press). Changes in stream discharge, water temperature, and chemical composition may be linked to a variety of causative factors ranging from increases in hydrothermal activity or magma intrusion, to earthquakes, ground deformation, or climate variations. In and around Yellowstone National Park (YNP), 14 stream gages are operated by the U.S. Geological Survey state water districts of Montana, Idaho, and Wyoming (http://mt.water.usgs.gov/, http://id.water.usgs.gov/, http:// wy.water.usgs.gov/ (all accessed on September 27, 2007). The data are archived as part of the National Water Information System (NWIS, http://waterdata.usgs.gov/nwis/rt (accessed on September 27, 2007)).

One hydrothermal area of intense interest is the Norris Geyser Basin, which is highly dynamic and contains the hottest measured temperatures within any geothermal reservoirs at Yellowstone $\left(238^{\circ} \mathrm{C}\right.$ in the Y12 research well; White and others, 1988). Friedman (in press) estimated that 98 percent of the surface hydrothermal discharge from the Norris Geyser Basin is channeled through Tantalus Creek. A stream gage, currently in place on Tantalus Creek, therefore, has the potential to provide information on the overall behavior of the geyser basin, as well as transient hydrothermal disturbances (anomalous changes in discharge or heat flow) that are occasionally observed (White and others, 1988; Fournier and others, 2002). Currently, the stream gage is deployed with instrumentation to determine water flow, water temperature, and precipitation. The data are transmitted by satellite uplink to NWIS. Nearby instrumentation at the Norris Museum (collected on data loggers) provides information on barometric pressure and air temperature. By analyzing the combined data, one can characterize the behavior of Tantalus Creek on a variety of timescales.

This report presents an analysis of the hydrologic and climate data collected at the Tantalus Creek stream gage and the Norris Museum to evaluate correlations among these data with the purpose of understanding diurnal, monthly and annual cycles in water flow and temperature. Lessons learned may be of use in defining thermal disturbances by discriminating between normal variations associated with meteorological phenomena from those due to changes in hydrothermal discharge related to subsurface dynamism. 


\section{Norris Geyser Basin}

Norris Geyser Basin is located approximately 20 miles south of Mammoth Hot Springs and just outside the northwest rim of the Yellowstone Caldera, which formed 640,000 years ago by the youngest of three caldera-forming eruptions at the Yellowstone volcano (Christiansen, 2001). The basin sits at the intersection of three regional landscape features - the 640 ka caldera, the Norris-Mammoth corridor (a zone of faulting, thermal activity, and volcanic vents that trends north from the caldera rim to Mammoth), and the eastern end of the east-west trending Hebgen Lake Fault system (White and others, 1988). A subsidence feature aligned along the Norris-Mammoth corridor allowed for the accumulation of thick deposits of Lava Creek Tuff during the 640 ka eruption. Today, the corridor hosts some of the region's youngest volcanism and abundant thermal activity (Christiansen and others, 2007). Norris itself contains more than 700 thermal features that are continually evolving, at least 70 of which have erupted as geysers (White and others, 1988), including Steamboat Geyser, the tallest active geyser in the world. Such dynamics generate highly complex hydrologic patterns.

\section{Drainage of Tantalus Creek}

Jaworowski and others (2006) divided the Norris Geyser Basin into nine hydrothermal sub-basins - Porcelain, One Hundred Spring Plain, Steamboat-Echinus-Emerald, Gray Lakes-Porkchop, Reservoir-Upper Tantalus, Lower Tantalus, Gap, West Gap, and Sulfur Dust (fig. 1). The basins represent distinct tributaries of sections of Tantalus Creek. The majority of these are drained by Tantalus Creek, which flows northward through Norris, collects the runoff of numerous thermal features, passes through a 0.58 ha pond (the Reservoir) and empties into the Gibbon River on the northwest side of the geyser basin. The Gap/West Gap and Sulfur Dust subbasins are exceptions to this drainage pattern and flow directly into the Gibbon River. The catchment area above the weir is $3.34 \mathrm{~km}^{2}$ ( $334 \mathrm{ha}$ ), and the length of the stream course between the source and the gaging station is 3,300 meters. The headwaters rise to 8,064 feet in elevation $(2,460$ $\mathrm{m}$ ), and the catchment is snow-covered, on average, from November through April. At the Tantalus gaging station the elevation is 7,460 feet $(2,270 \mathrm{~m})$ and the channel is 5.2 $\mathrm{m}$ wide. Chloride concentrations are very high in the creek (400-550 ppm during base flow in August and September), suggesting the water is mostly derived from hot springs (Norton and others, 1989; Ball and others, 2001; Ball and others, 2002). Tantalus is a very small creek relative to other rivers in Yellowstone Park, with a maximum springtime flow of less than $10 \mathrm{cfs}$ (cubic feet per second, each of which is equal to $28.31 \mathrm{~s}^{-1}$ ). Tantalus Creek flows into the Gibbon River, which commonly transmits over $300 \mathrm{cfs}$ in the springtime. The water in Tantalus Creek is almost entirely derived from hot springs from Norris Geyser Basin (Jaworowski and others, 2006), so that continuous monitoring of the creek provides a valuable means for detecting changes to the Norris hydrothermal system as a whole.

\section{Data Sources}

The hydrologic and climate data used in this analysis came from several sources. The discharge and temperature of Tantalus Creek were measured at a weir constructed in 1987 and located at the northwest end of the creek, prior to its confluence with the Gibbon River at 7,460 feet above sea level. A gaging station was operated informally at the site from 1987 to 2003, at which time the USGS Montana District upgraded the site and added realtime capabilities. A precipitation gage was later added and all the data are available through NWIS at http://waterdata.usgs.gov/nwis/ uv?06036940 (last accessed on September 27, 2007). All three data sets (water temperature, flow, and precipitation) are recorded, transmitted, and archived on local time (either MST or MDT) at 15-minute increments. Local air temperature was recorded on Mountain Standard Time (MST) by a Hobo ${ }^{\circledR} \mathrm{H} 8$ temperature logger (Onset Computer Corp.) located at the Norris Museum at 7,575 feet $(2,310 \mathrm{~m})$, operated by the YNP geology program and measured every 4 minutes. Eruption times of Echinus Geyser were determined from records of water temperature in the geyser's outflow channel, also measured by a Hobo ${ }^{\circledR} \mathrm{H} 8$ temperature logger on MST deployed by the YNP geology program. Temperature spikes in the channel indicate an eruption, and the date and time of these spikes were documented to create a record of eruption times for this geyser. All data reported and plotted in this paper have been converted to MST. Together, this suite of hydrologic and climate data for 2005 was analyzed to evaluate correlations among the datasets. The data are available in a supplementary data file (Tantalus2005data.xls).

\section{Observations}

\section{Wintertime Systematics}

The Tantalus Creek hydrograph displayed characteristic patterns during the various seasons of 2005. In this report, we define "summer" and "winter" patterns and intermediate behavior evident during the spring and fall. The winter pattern is apparent when daily average air temperatures are consistently below $0^{\circ} \mathrm{C}$ (December, January, February for 2004-2005; fig. 2).

An example of the winter pattern is shown in figure 3, which displays air and water temperature (in degrees Celsius), stream flow (in cubic feet per second or cfs), and precipitation (inches, equal to $2.54 \mathrm{~cm}$ ) from February 22 to March 1, 2005. During this 7-day period, there was negligible precipi- 


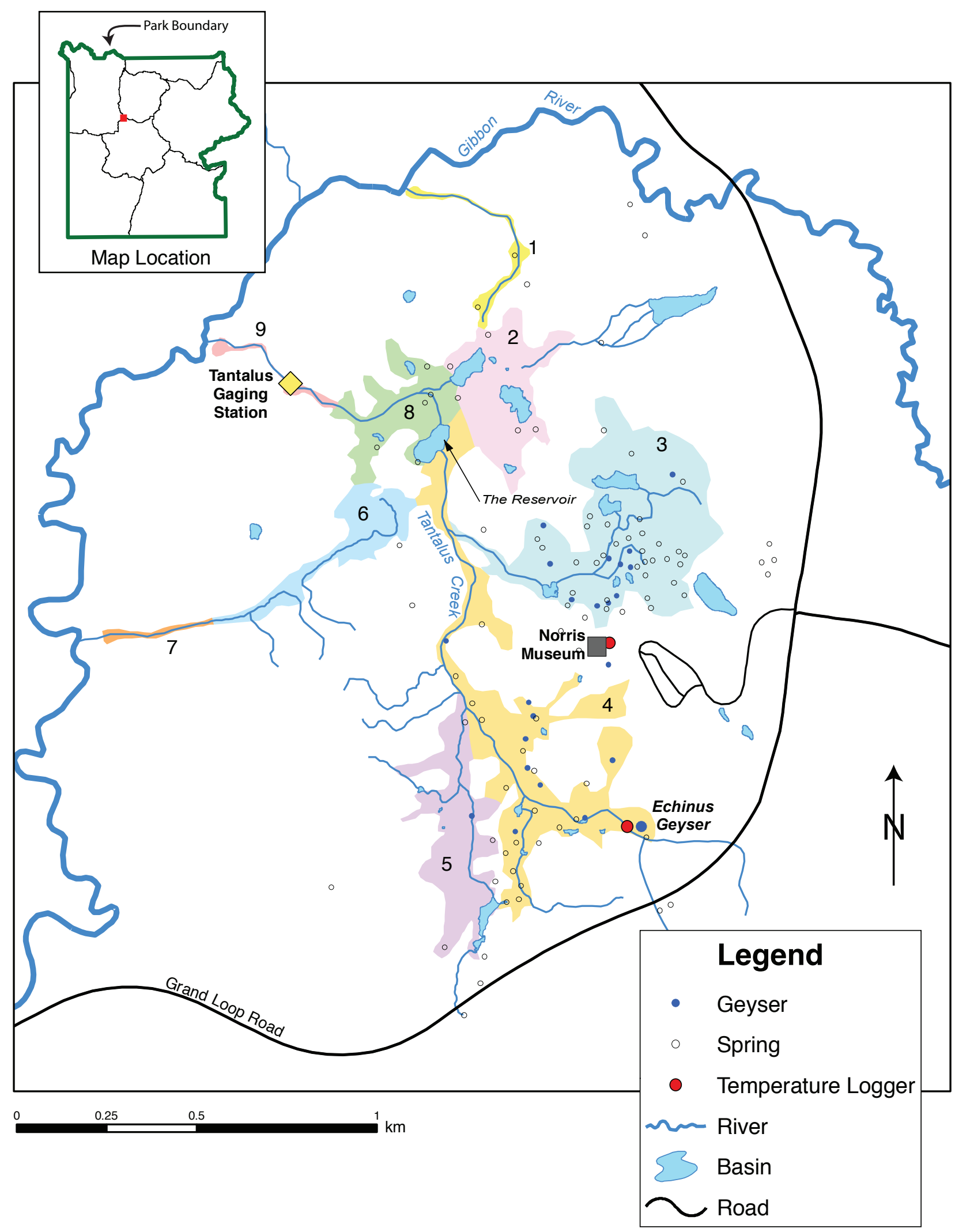

Figure 1. Area map of Norris Geyser Basin, Yellowstone National Park, showing geographic features mentioned in the text, monitoring sites at Tantalus Weir and Norris Museum, and hydrologic subbasins. Geysers and springs have been simplified for clarity. Subbasin codes are: 1 = Sulfur Dust, 2 = Hundred Spring Plain, 3 = Porcelain, 4 = Steamboat-Echinus-Emerald, $5=$ Gray Lakes-Porkchop, $6=$ Gap, 7 = West Gap, 8 = Reservoir-Upper Tantalus, $9=$ Lower Tantalus. 


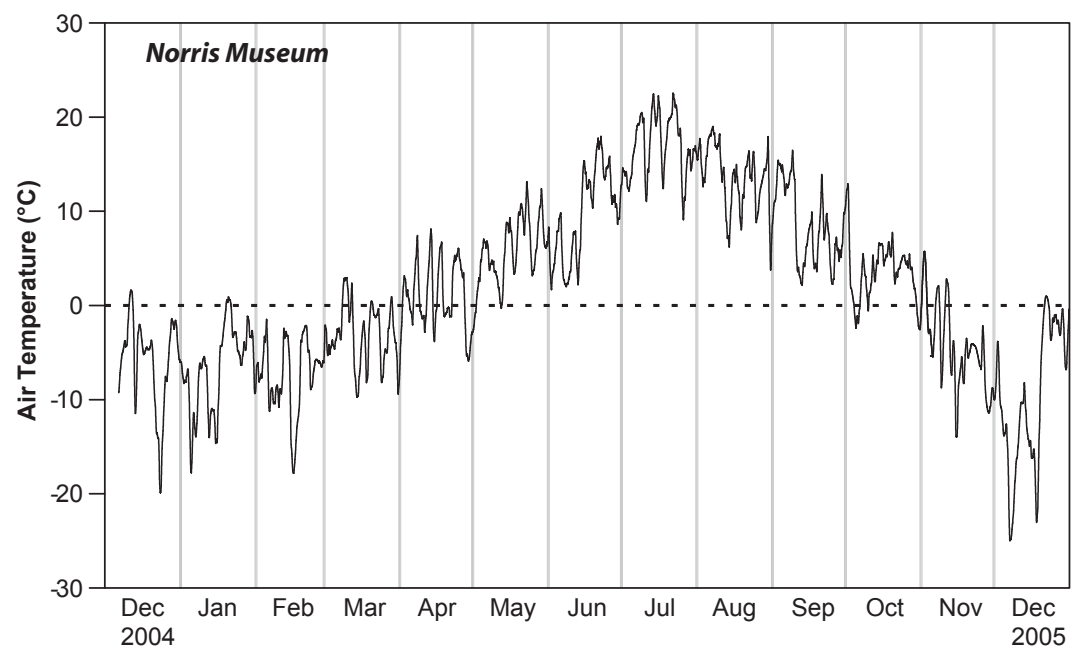

Figure 2. Daily average air temperatures for Norris Geyser Basin from December 2004 through December 2005, measured at the Norris Museum. Dashed line represents $0^{\circ} \mathrm{C}$. Vertical gridlines divide the months.
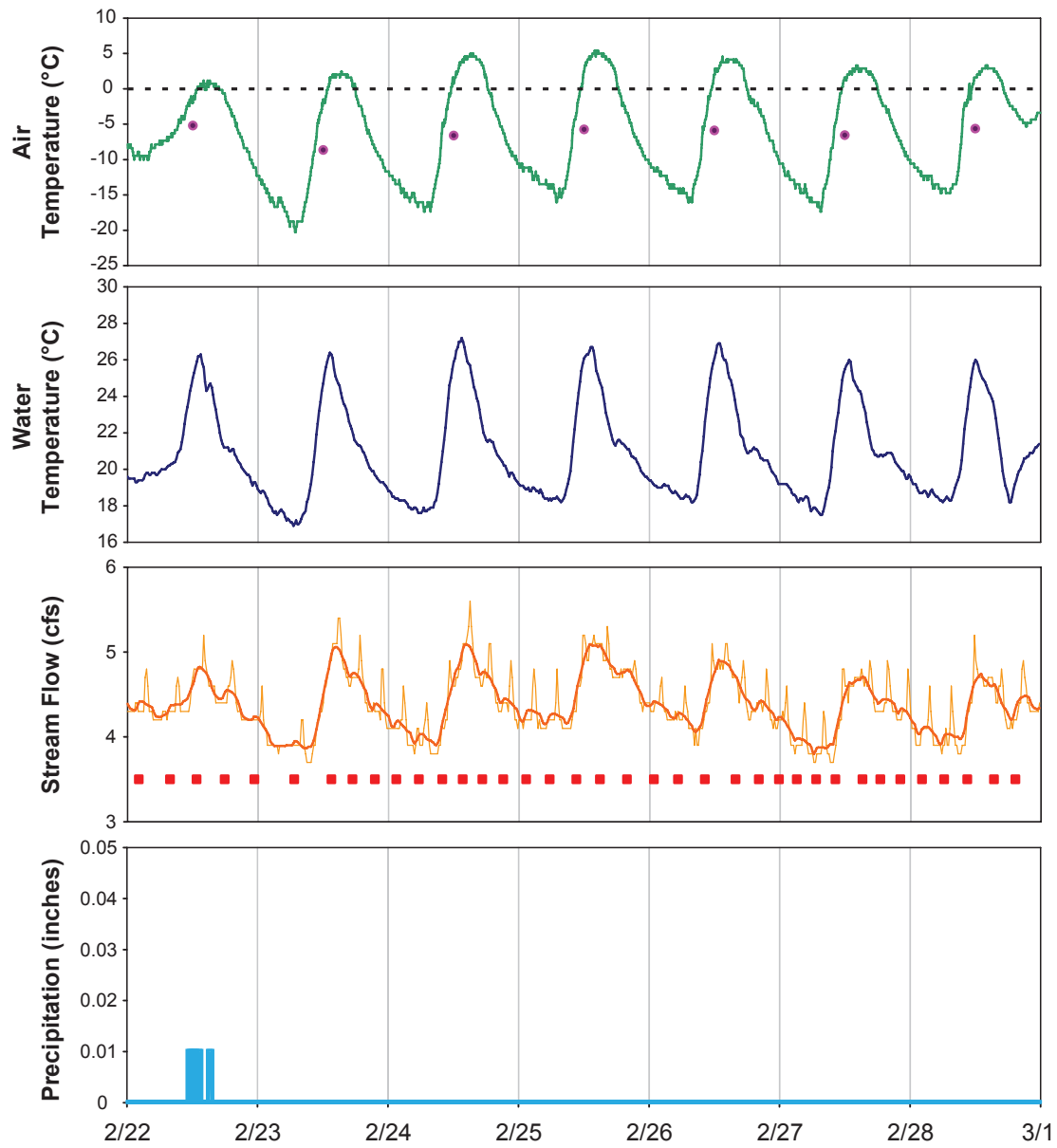

Figure 3. Air temperature at Norris Museum, and water temperature, stream flow, and precipitation at Tantalus Weir for the week of February 22 to March 1, 2005. Dashed line on the air temperature graph represents $0^{\circ} \mathrm{C}$. Purple dots indicate the average air temperature for that day. Red squares on the stream flow graph mark the time of eruptions of Echinus Geyser. The lighter orange flow curve is the actual stream flow data, whereas the thicker, darker orange curve is a 3-hour average of those data, taken in order to improve the clarity of the diurnal pattern. All X-axes are the same. Vertical gridlines are placed at midnight to divide each day. 

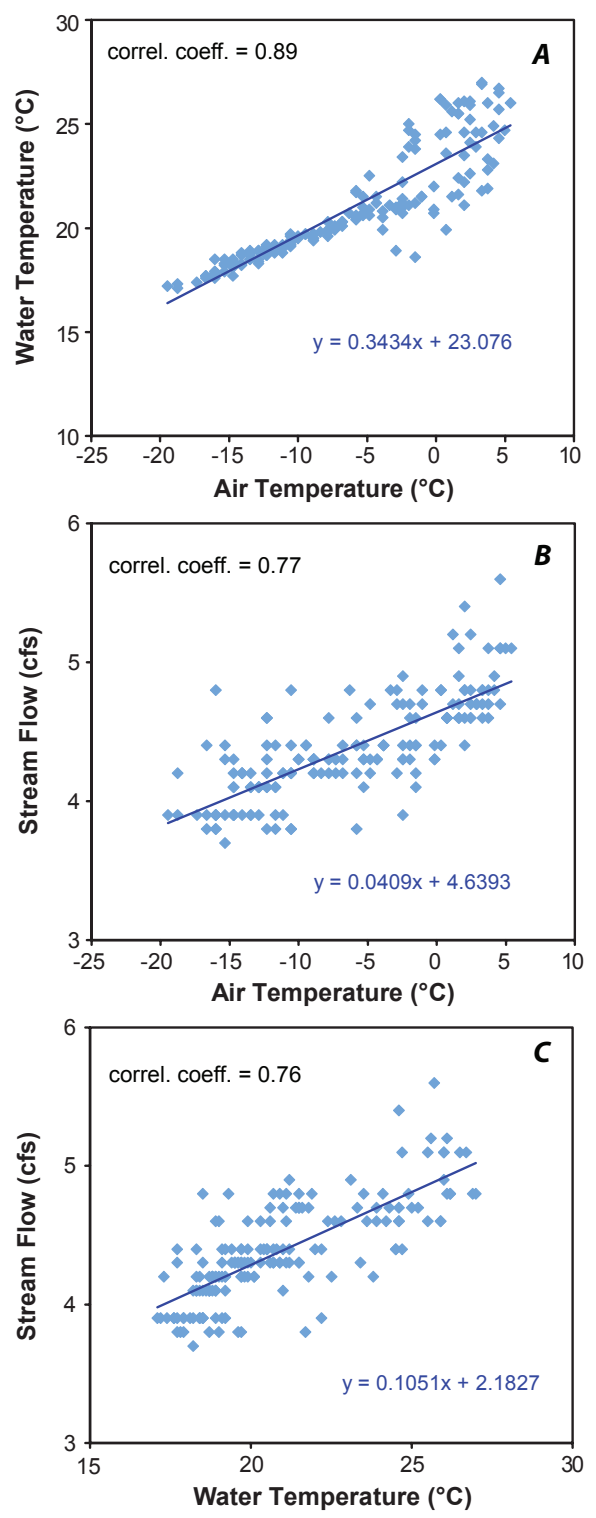

Figure 4. Correlations between $(A)$ air and water temperature, $(B)$ air temperature and stream flow, and $(C)$ water temperature and stream flow for the week of February 22 to March 1, 2005. Correlation coefficients discussed in text are indicated.

tation, and a clear diurnal signal is shown in the other three parameters. Air and water temperature were closely correlated with asymmetric peaks that rose rapidly in the morning ( 08:30) until early afternoon ( 14:00) and then fell more slowly until reaching a minimum value the following morning at about 07:00, immediately prior to the next cycle. Figure 4A illustrates air temperature-water temperature relations for this week, which has a correlation coefficient of 0.89 . During this week, air temperatures fluctuated between daily lows of $-15^{\circ} \mathrm{C}$ to $-20^{\circ} \mathrm{C}$ and highs from 0 to $5^{\circ} \mathrm{C}$. Daily average air temperatures are shown as small purple dots in figure 3 , and varied between $-5^{\circ}$ and $-10^{\circ} \mathrm{C}$ during the 7 -day period.
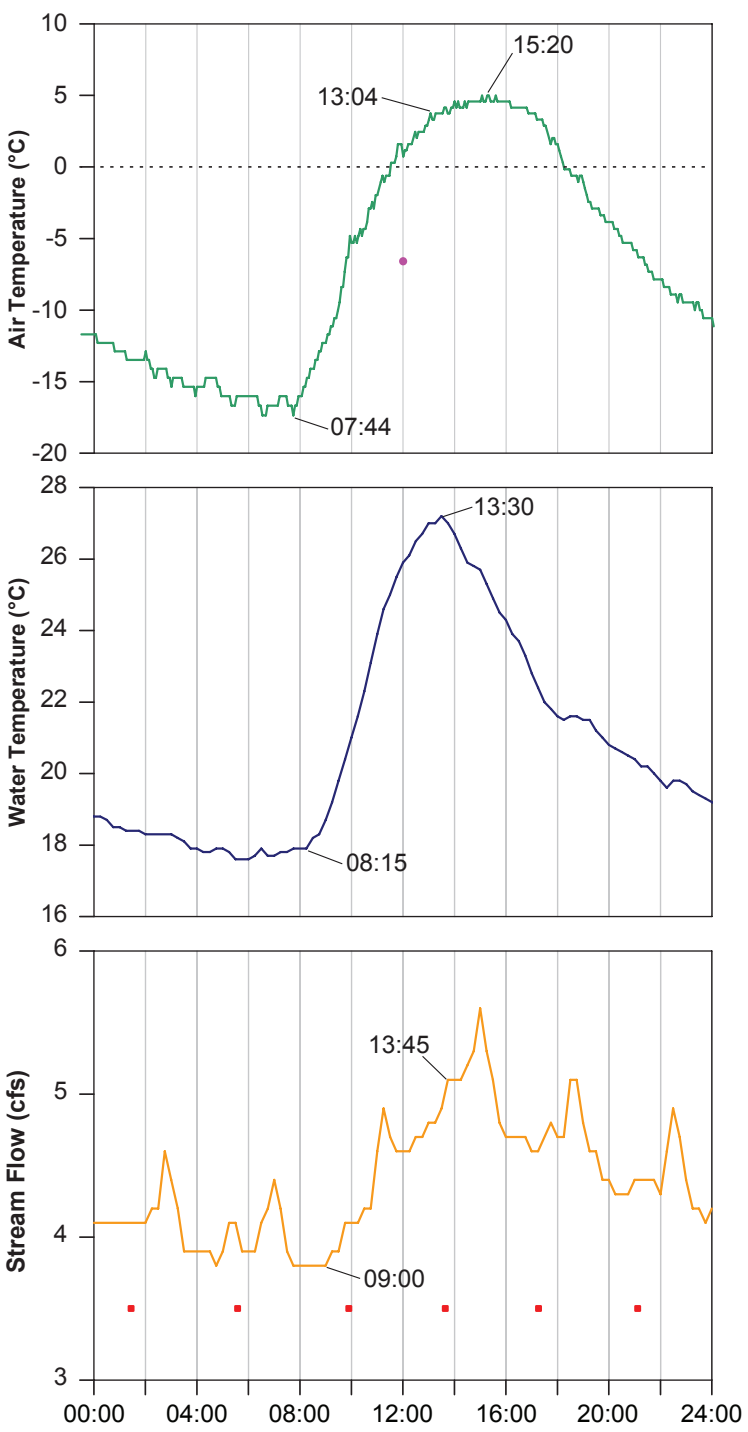

Figure 5. Close-up view of data from February 24, 2005, showing air temperature, water temperature, and stream flow (there was no precipitation on February 24). Symbols are as in figure 3. The 3-hour average stream flow curve has not been included. The times of day of certain hydrologic events are indicated, as mentioned in the text. Vertical gridlines mark every 2 hours.

Tantalus Creek water temperatures at the weir were significantly higher, ranging from daily lows of about $17^{\circ} \mathrm{C}$ to highs around $26^{\circ} \mathrm{C}$. Stream flow showed a similar pattern, rising abruptly in the morning to a peak in the early afternoon at about 13:45 and then decreasing slowly. Stream flow correlated positively with air temperature with a correlation coefficient of 0.77 , and with water temperature with a correlation coefficient of 0.76 (fig. 4B-C). The flow varied between about 4 and 5 cfs each day.

During the period illustrated in figure 3, Echinus Geyser was in frequent eruption, averaging 4 hours and 28 minutes between eruptions. The signal of the eruption was clearly 
evident in the stream flow data, resulting in small spikes of $\sim 1,170$ cubic feet and lasting approximately 70 minutes. The spikes followed Echinus eruptions by 85 minutes, implying that the water traveled at $\sim 0.40 \mathrm{~m} / \mathrm{s}$ to travel the $\sim 2,000 \mathrm{~m}$ from Echinus to the weir. Concurrent with the obvious spikes in flow were smaller, less pronounced bumps in the water temperature curve, indicating that a slight increase in water temperature was also associated with eruptions of Echinus Geyser. These bumps are discernable for the entire week of February 22-March 1, 2005, but are only noticeable in close-up view, as in figure 5 .

Figure 5 displays a detailed view of data from February 24,2005 , in order to examine more precisely the timing of events that occurred during the course of a typical day during the week shown in figure 3 . Air temperature abruptly increased at 07:44, followed 46 minutes later by the same increase in water temperature. The rise in air temperature became more gradual around 13:00 and by 14:00 it reached a more or less steady plateau that persisted for the next several hours. The maximum air temperature for the day occurred at 15:20, after which it fell gradually. Water temperature, however, reached its maximum at 13:30 and immediately began to fall again, resulting in a sharper peak. It is interesting to note that water temperature fell while air temperature remained steady. Stream flow, which began climbing rapidly at 09:00, reached its maximum (excepting the periodic spikes due to eruptions of Echinus Geyser) at 13:45 and then fell more gradually for the rest of the day.

To summarize, in the winter, stream flow increased steeply up to a defined peak in the mid-afternoon, and then gradually decreased through the rest of the day, down to a minimum point that took place in the early morning. Minor precipitation did not seem to alter this general pattern.

\section{Summertime Systematics}

Summertime hydrologic conditions were defined by daily average air temperatures that were consistently above $0^{\circ} \mathrm{C}$ (May, June, July, August, September for 2005; see fig. 2). Figure 6 displays air and water temperature, stream flow, and precipitation from September 1-8, 2005. During this 7-day period, there was no precipitation and a clear diurnal pattern is shown in the other three parameters. Changes in air and water temperature were closely correlated, but the two curves did not have identical shapes. Both parameters rose rapidly from early morning ( 06:00) to mid-day $(\sim 11: 30)$ and then fell more slowly. However, while air temperature fell constantly until reaching a minimum value the following morning (around 05:00), water temperature fell only until the evening (about 18:30), at which point a secondary peak appeared. Water temperature rose until 21:00 and afterwards fell until 05:30 the following morning, immediately before the next cycle. Additionally, air temperature displayed generally smooth, asymmetric peaks while water temperature displayed more irregular, yet symmetrical peaks. During this week, air tem- peratures fluctuated between daily lows of $-1{ }^{\circ} \mathrm{C}$ to $5^{\circ} \mathrm{C}$ and highs from $21^{\circ} \mathrm{C}$ to $26^{\circ} \mathrm{C}$. Daily average air temperatures are shown as small purple dots in figure 6 and varied between $11^{\circ} \mathrm{C}$ and $15^{\circ} \mathrm{C}$ during the 7-day period. Tantalus Creek water temperatures at the weir were significantly higher, ranging from daily lows of about $22^{\circ} \mathrm{C}$ to highs around $31^{\circ} \mathrm{C}$. Stream flow showed a completely different pattern, rising in the afternoon (around 17:00) and reaching a broad plateau that lasted overnight and into the next morning (from around 22:30 to 10:00) and then decreasing to a minimum value in the afternoon (about 16:30), immediately prior to the beginning of the next cycle. Stream flow varied from minima $\sim 3 \mathrm{cfs}$ to maxima $\sim 3.6 \mathrm{cfs}$. At this time, Echinus was dormant.

Figure 7 displays data from September 2, 2005, plus the last 8 hours of September 1 and the first 8 hours of September 3. On September 2, air temperature began to rise rapidly at 05:08, followed 37 minutes later by the same behavior in water temperature, at 05:45. Air temperature plateaued by 10:25, with the absolute peak temperature for the day at 12:24. At 16:12, the air began to cool gradually, falling to a minimum at 05:20 the next morning. The water reached its maximum temperature at 10:15 and then began to drop, slowly at first, but more quickly after 12:00. It fell to a minimum at 18:15 but then began to climb again to a secondary peak at 21:15. At 22:00, water temperature fell again to another minimum at 6:45 the next morning, slightly after air temperature had begun to rise. On September 1, stream flow sharply began to increase at 18:45, the same time that water temperature began rising to its secondary maximum. Stream flow reached a plateau at 20:45 and maintained generally constant values until 12:00 on September 2, at which point flow dropped off abruptly until 14:45. A trough of low values persisted until 17:30, when the next cycle began, and flow increased to the next plateau at 22:00.

Figure 8 displays the relationship between water and air temperature for the week of September 1-8, 2005, which has a correlation coefficient of 0.76 . On this plot, the data points that fall below $14.5-15^{\circ} \mathrm{C}$ in air temperature are tightly clustered and have a slope of $\sim 0.13$. The data points above $14.5-15^{\circ} \mathrm{C}$ in air temperature are more scattered and have a slope of 0.76 . This implies that as the air heats up, water temperature seems to be more sensitive to air temperature. Summertime correlations between flow and both water and air temperatures are very poor (coefficients are -0.06 and -0.51 , respectively).

There was a significant precipitation event on August 10,2005 , between $12: 15$ and $14: 15$, when 0.34 inches (8.6 $\mathrm{mm}$ ) of rain fell (fig. 9). During this time, air temperature dropped precipitously from $26.7^{\circ} \mathrm{C}$ at $10: 52$ to $10.2^{\circ} \mathrm{C}$ at $11: 32$. Water temperature dropped from $35.9^{\circ} \mathrm{C}$ at $11: 45$ to $20^{\circ} \mathrm{C}$ at $12: 45$. Stream flow spiked abruptly from $3.6 \mathrm{cfs}$ at 12:15 to $11 \mathrm{cfs}$ at 13:45.

Echinus Geyser erupted occasionally during the period from August 9-16, 2005 (fig. 9). There was no apparent regular interval between eruptions. The signal of the erup- 

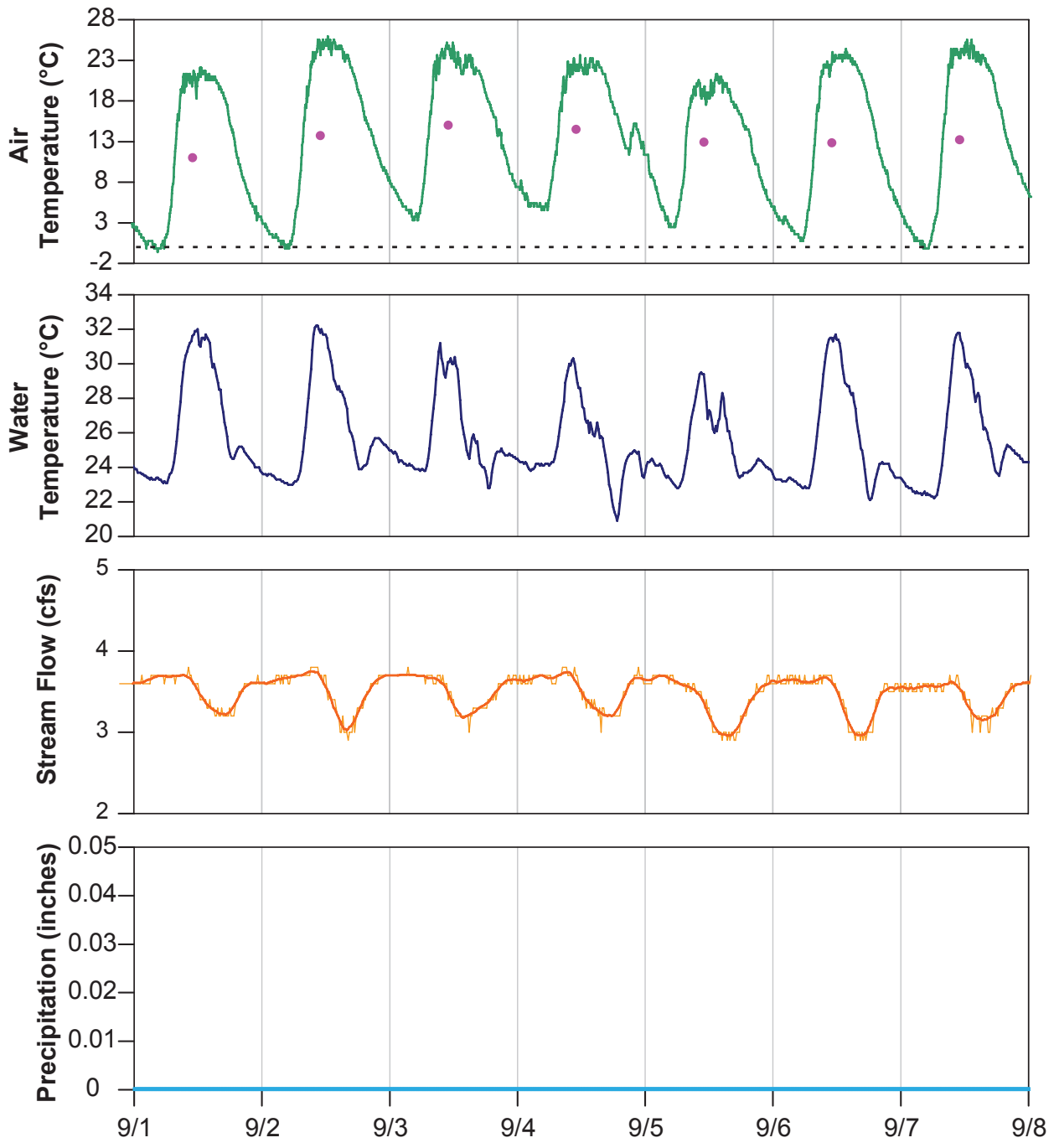

Figure 6. Air temperature, water temperature, stream flow, and precipitation for the week of September 1-8, 2005. Symbols as in figure 3.

tion was clearly evident in the stream-flow data, resulting in small spikes of $\sim 1,350$ cubic feet of water (38,000 liters) over approximately 90 minutes. The spikes followed Echinus eruptions by 80 minutes, implying that the water traveled at $\sim 0.42 \mathrm{~m} / \mathrm{s}$ across $\sim 2,000 \mathrm{~m}$ from Echinus to the weir. No associated water temperature increase was observed at the Tantalus gaging station.

To summarize: in contrast to the winter pattern, the maxima for flow occurs overnight and does not correspond temporally with air and water temperatures, which have maxima in the early afternoon. Furthermore, the shape of flow curve does not mimic that of the air or water curves. Summer flow exhibits broad flat-topped highs, whereas the minima are narrow troughs that occur in the late afternoon. This characteristic flow curve will be referred to as the "summer-type" flow regime. The water and air temperature maxima are correlated, but there is a secondary maximum in water temperature in the evening. Precipitation events coincide with a marked increase in flow and decrease in air and water temperature.

\section{Springtime Systematics}

Springtime is characterized by increasing daily average air temperatures that fluctuate above and below $0^{\circ} \mathrm{C}$ (March and April for 2005; see fig. 2). During the transition from winter to summer, traces of the two distinct hydrologic patterns described above can still be found, but the patterns are often obscured by the highly variable weather conditions that accompany the change in seasons. Figure 10 displays air and water temperature, stream flow, and precipitation from March 7-15, 2005. During this 8-day period, there was negligible precipitation, a moderately strong diurnal pattern in water and 

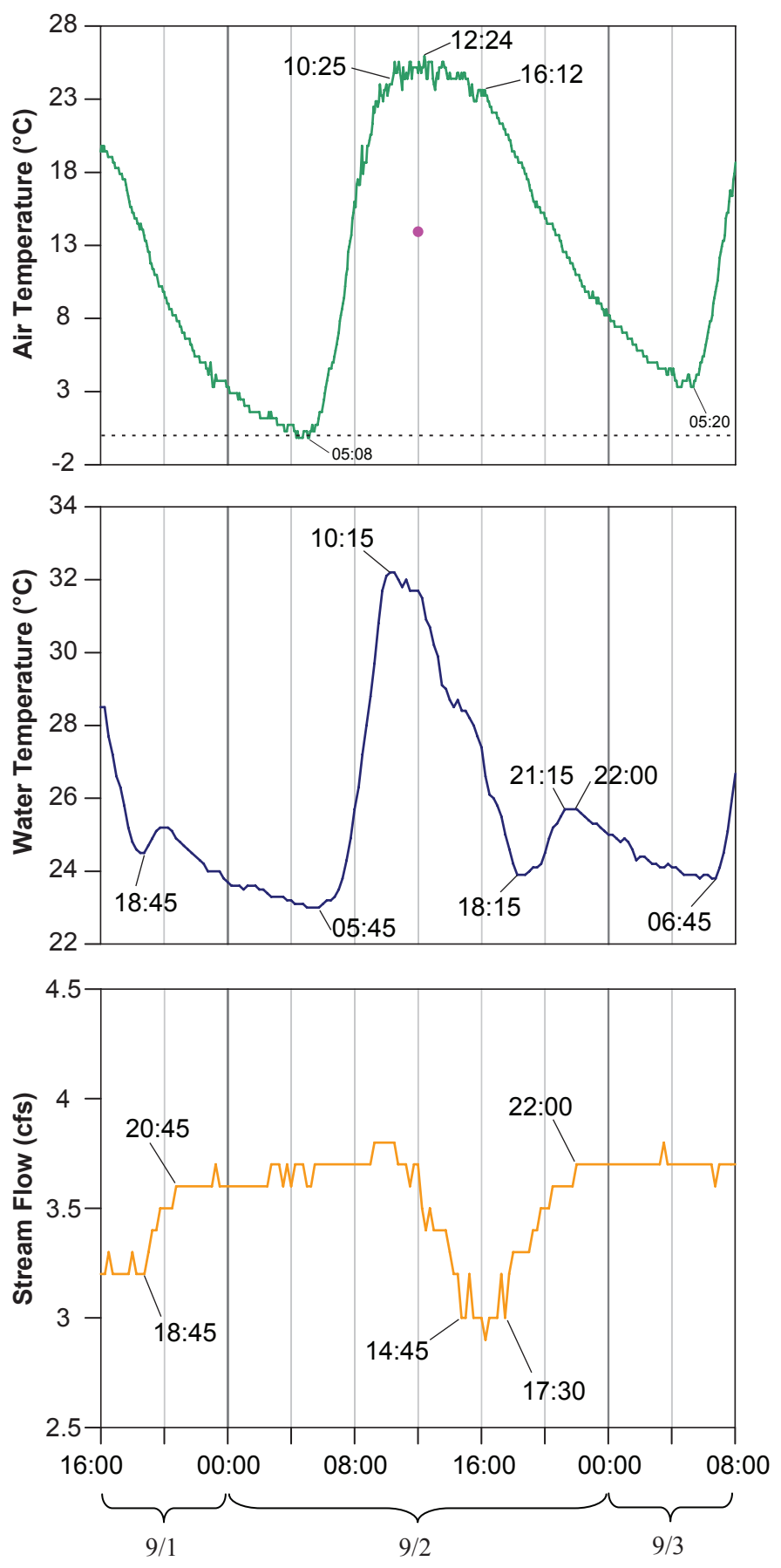

Figure 7. Close-up view of September 2, including the last 8 hours of September 1 and the first 8 hours of September 3. Shows air temperature, water temperature, and stream flow (there was no precipitation during this period). Symbols are as in figure 3. The 3-hour average stream flow curve has not been included. The times of day of certain hydrologic events are indicated, as mentioned in the text. Vertical gridlines mark every 4 hours.

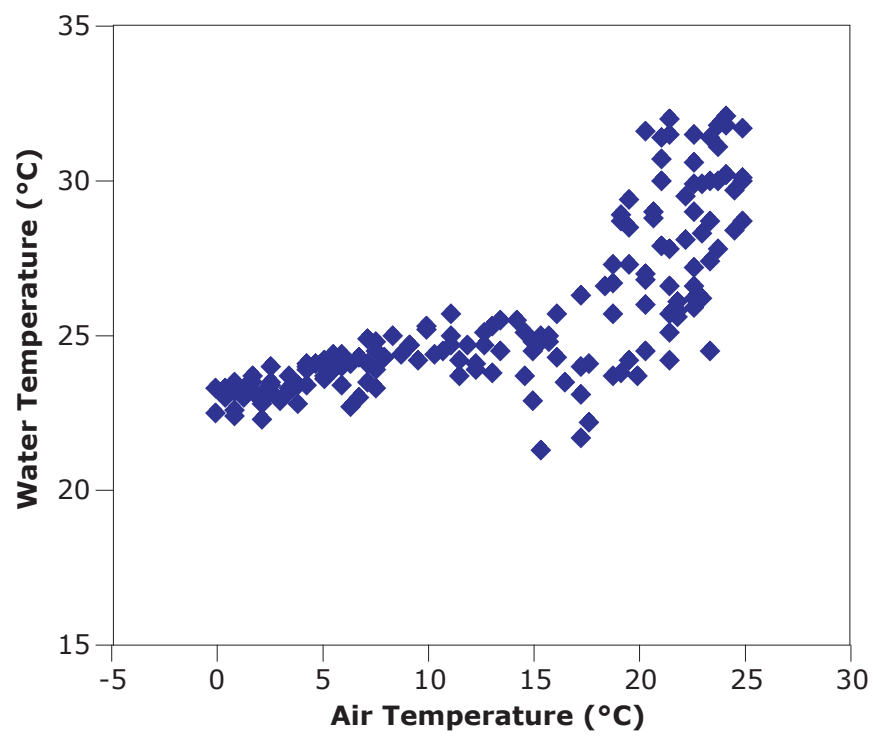

Figure 8. Plot of air temperature versus water temperature for the week of September 1-8, 2005. During cold weather, water temperature increases more slowly with air temperature than during warmer weather.

air temperature, and a weak diurnal pattern in stream flow. In general, signals tend to be irregular and less predictable than those of the winter or summer. Air and water temperature daily maxima were closely correlated in time with irregularly shaped peaks that rose approximately from 07:00 to 13:00. Air temperature fell to a minimum value sometime between 04:00 and 07:00, whereas water temperature tended to display secondary maxima lasting from 19:00 in the evening to 07:00 the next morning. Sometimes this was not the case, as on March 11 when water temperature did not rise to a secondary peak. During this period, air temperatures fluctuated between $-16^{\circ} \mathrm{C}$ and $9^{\circ} \mathrm{C}$, with daily highs and lows varying significantly from one day to the next. Daily average air temperatures (purple dots in fig. 10) varied between $-10^{\circ} \mathrm{C}$ and $3^{\circ} \mathrm{C}$ during the 8 -day period. Tantalus Creek water temperatures were significantly higher, ranging from daily average lows of about $18^{\circ} \mathrm{C}$ to average highs around $25^{\circ} \mathrm{C}$. Stream flow showed a shifting pattern, sometimes rising abruptly in the morning to a sharp peak at $\sim 14: 45$ followed by a slower decrease (as on March 7, March13, and March 14), and sometimes rising in the afternoon at $\sim 16: 30$, reaching a broad plateau that lasted from 20:00 to 9:00 the next morning, and then decreasing to a minimum value at noon (as on March 9 and March 10). Stream flow varied from minima $\sim 3.7 \mathrm{cfs}$ to maxima $\sim 6 \mathrm{cfs}$.

The first occurrence of the summer flow pattern for the 2005 season was on March 9, and it appeared again sporadically on April 2 and April 7 before becoming the normal pattern in mid-April. The winter pattern was frequent in early March (as in fig. 10 on March 7, March 13, and March 14, for example), but happened less often as the month progressed, 

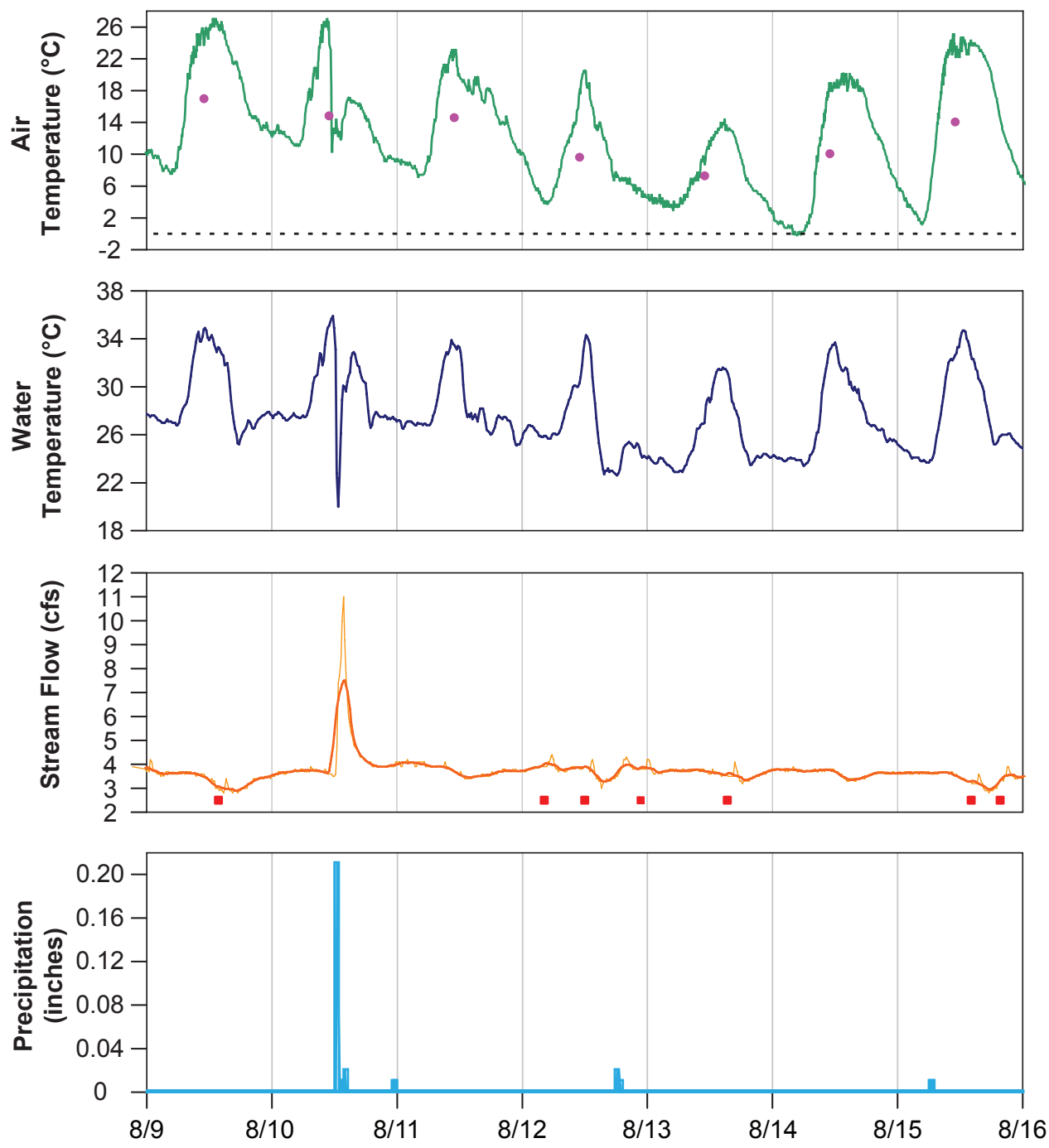

Figure 9. Air temperature, water temperature, stream flow, and precipitation for the week of August 9-16, 2005. Symbols are as in figure 3.

with the last occurrence on March 25. Data from some parts of the spring season did not exhibit the easily identifiable patterns of the winter or summer. Instead, there was an apparent lack of regular diurnal variation (fig. 11). During the week of April 17-24, 2005, for example, stream flow exhibited the broad overnight highs associated with summertime on April 17, April 22 and April 23, but no regular diurnal pattern from April 18 through April 21. The alternation of signals (from winter pattern to summer pattern and back again) occurred for approximately 8 weeks until early May when the transitional spring period seemed finally to give way to the summer flow pattern.

During the period illustrated in figure 10, Echinus Geyser was in frequent eruption, averaging 4 hours and 52 minutes between eruptions. The signal of the eruption was clearly evident in the stream-flow data, resulting in small spikes of $\sim 1,080$ cubic feet and lasting approximately 80 minutes. The spikes followed Echinus eruptions by 90 minutes, implying that the water traveled at $\sim 0.37 \mathrm{~m} / \mathrm{s}$ across $\sim 2,000 \mathrm{~m}$ from Echinus to the weir. No associated water-temperature increase was apparent at the Tantalus gaging station.

\section{Autumn Systematics}

Autumn was characterized by decreasing daily average temperatures that fluctuated above and below $0^{\circ} \mathrm{C}$ (October and November for 2005; see fig. 2). Figure 12 displays air and water temperature, stream flow, and precipitation from October 26 to November 2, 2005. During this 7-day period, there was a small but significant precipitation event, a weak diurnal pattern shown by air temperature, and a near lack of diurnal pattern shown in the other two parameters. Air temperature displayed a strong diurnal signal on October 26 with 

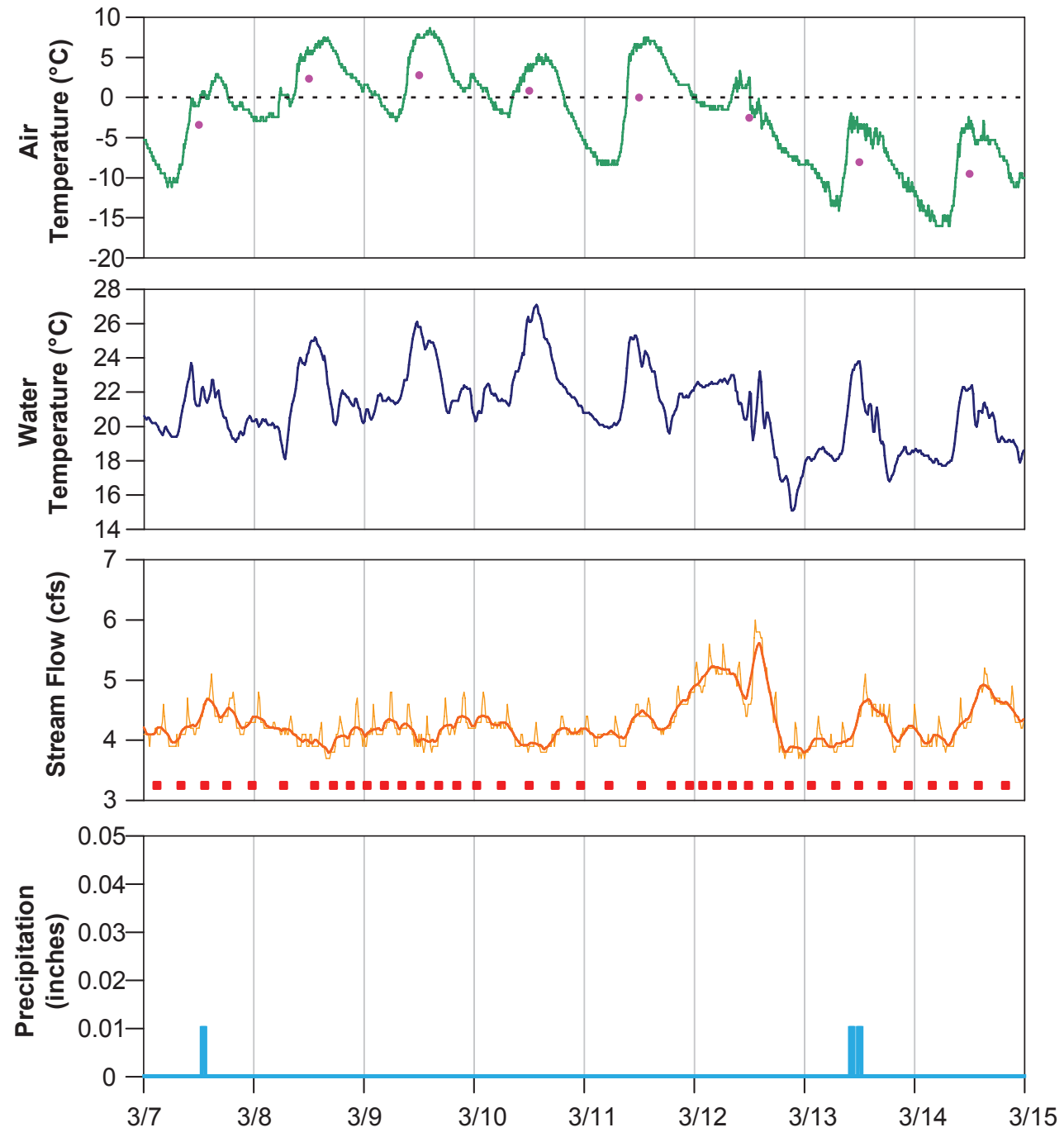

Figure 10. Air temperature, water temperature, stream flow, and precipitation for the 8-day period of March 7-15, 2005. Symbols are as in figure 3.

an asymmetrical peak that rose rapidly from $-1.1^{\circ} \mathrm{C}$ at $07: 30$ to $12.6^{\circ} \mathrm{C}$ at $11: 30$ and then fell more slowly until reaching a minimum value at midnight. Later in the week, however, the signal weakened as daily average temperatures fell from $3.8^{\circ} \mathrm{C}$ on October 27 down to $-2.1^{\circ} \mathrm{C}$ on October 30 , and then rose again to $4.3^{\circ} \mathrm{C}$ on November 1 . On most days, there was a peak in air temperature at about noon, but it was very poorly defined. Water temperature also displayed a strong diurnal signal on October 26, rising rapidly from 08:00 to 11:00 and falling more gradually to a minimum at 17:15. For the rest of the week, however, water temperature did not display any diurnal pattern, generally falling from a high of $26^{\circ} \mathrm{C}$ on October 27 to a low of $18^{\circ} \mathrm{C}$ on October 31 and then slowly rising again. The stream flow curve shown in figure 12 began with a broad, flat-topped flow high ending at 10:15 on October 26 and falling to a minimum at 16:00. After this, the flow signal became irregular and did not display a diurnal pattern for the remainder of the week. Flow varied from minima $\sim 3.7 \mathrm{cfs}$ to maxima $\sim 6.3 \mathrm{cfs}$

The effect of precipitation events can also be noted in the data. Between October 27 at 07:30 and October 28 at $09: 15$, a cumulative amount of 0.25 inches of rain fell. Concurrently, stream flow rose abruptly from $4.2 \mathrm{cfs}$ to 6.3 cfs (fig. 12). Water and air temperature did not seem to be equivalently influenced by the precipitation event.

Although in general the autumn flow signal was dominated by precipitation, there were occasional diurnal patterns. In the beginning of October, the broad overnight summerpattern highs in flow were frequent, as in figure 13. When these existed, water temperature displayed the secondary maxima, although more weakly than in the summer. Minimum flow came in the afternoon around 15:30-16:00. The secondary peak in water temperature disappeared over the 

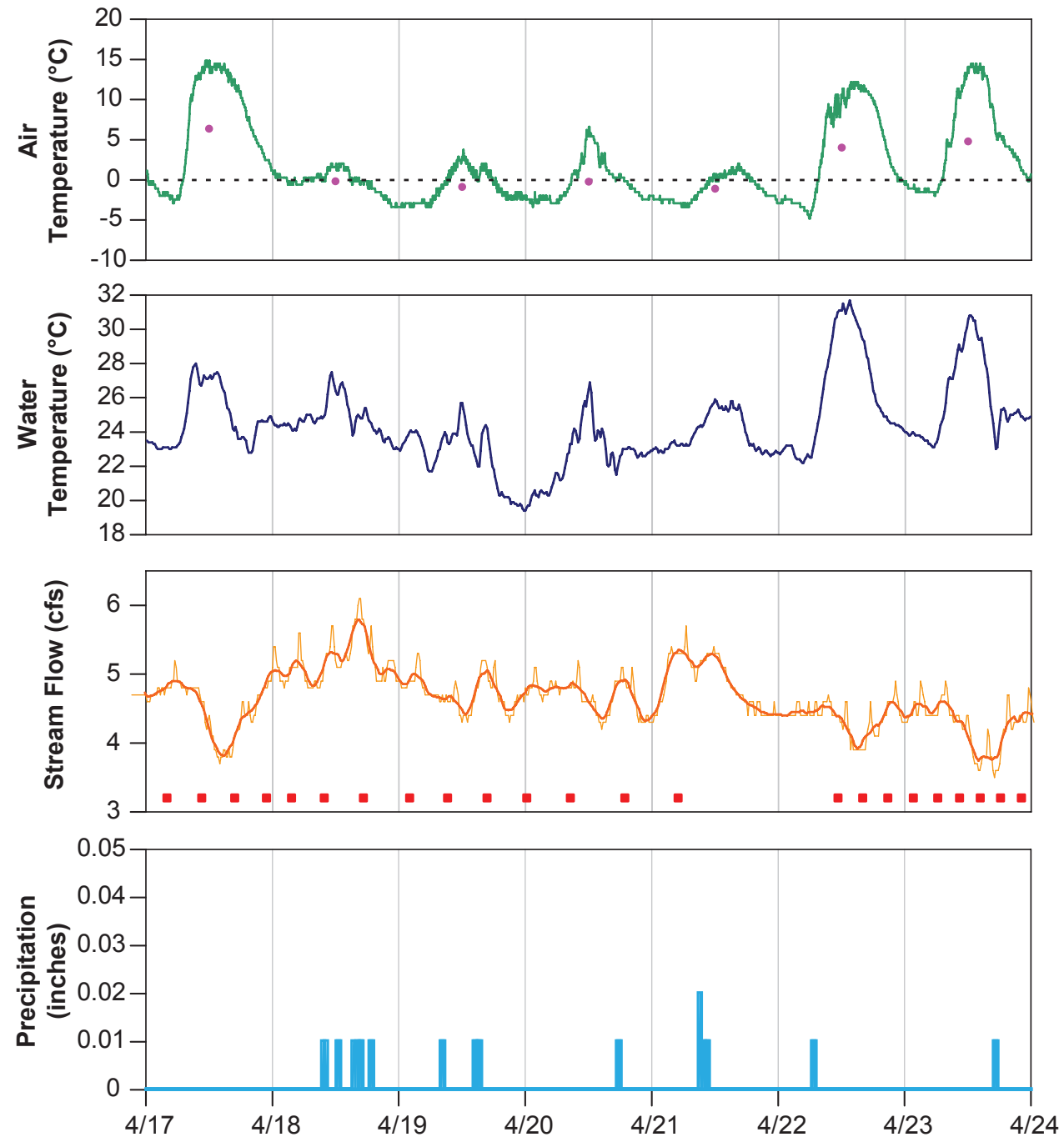

Figure 11. Air temperature, water temperature, stream flow, and precipitation for the week of April 17-24, 2005. Symbols are as in figure 3.

course of October, along with the nighttime flow high. The last occurrence for the season of the summer flow pattern was on October 26 (fig. 12), and this gave way to a non diurnal flow signal that persisted until the first appearance of the winter flow pattern on November 9 (fig. 14). Here maximum flow displayed asymmetrical peaks that rose abruptly in the morning to peak at 14:00 and then decreased slowly. As November progressed, rain diminished and a diurnal, winter pattern was regularly present (fig. 15).

During the period illustrated in figure 14, Echinus Geyser was in frequent eruption, averaging 4 hours and 55 minutes between eruptions. The signal of the eruption was clearly evident in the stream flow data, resulting in small spikes of $\sim 1,170$ cubic feet and lasting approximately 80 minutes. The spikes followed Echinus eruptions by 79 minutes, implying that the water traveled at $\sim 0.42 \mathrm{~m} / \mathrm{s}$ to arrive at the weir, $\sim 2,000 \mathrm{~m}$ away. No associated water temperature increase was discernible at the Tantalus gaging station.

\section{Discussion}

\section{Characteristics of Tantalus Creek}

Tantalus Creek is unusual in its relatively low and constant flow. Stream flow rarely dips below $2 \mathrm{cfs}$, and only during large storms does it rise above 6 cfs. The numerous fractures in the Lava Creek Tuff may provide sufficient permeability to provide relatively constant base-flow conditions (see Jaworowski and others, 2006). Similarly, the relatively warm stream temperatures reflect the high proportion of water sourced from hot-spring discharge and also the warm ground temperatures in the streambed (Jaworowski and others, 2006). 

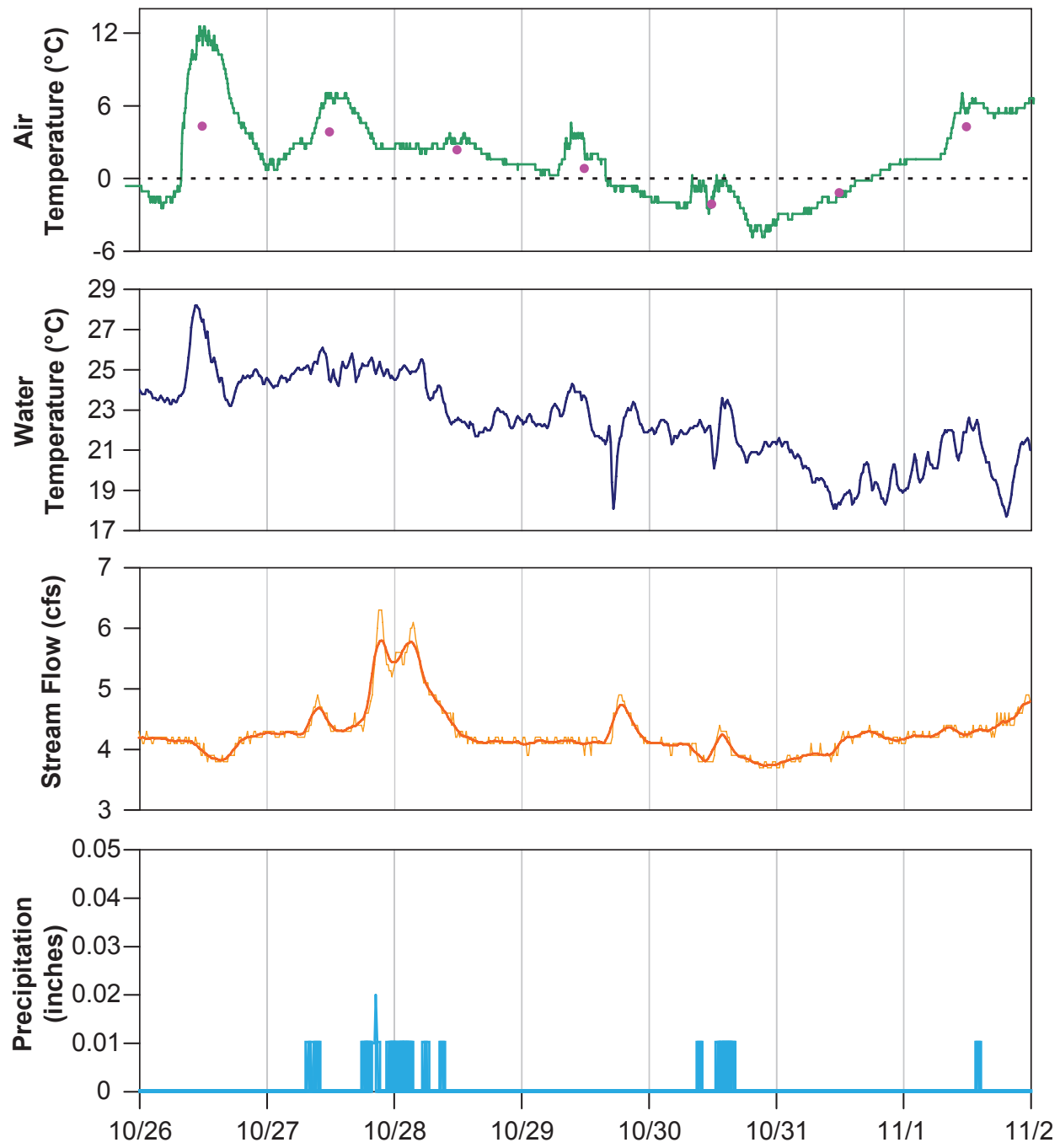

Figure 12. Air temperature, water temperature, stream flow, and precipitation for the week of October 26 to November 2, 2005. Symbols are as in figure 3.

\section{Wintertime Behavior}

The typical winter-type flow pattern (fig. 3) was most likely related to solar heating and melting of ice and snow in the creekbed. The more narrow curve for water temperature than air temperature (see for example, fig. 5) seems to indicate that solar radiation rather than air temperature is the direct influence on water temperature. Though solar radiation was not measured at Norris in 2005, more recent data for Yellowstone indicates a tight correlation between solar radiation and water temperature at Tantalus Creek (J.B. Lowenstern, unpub. data). However, because solar radiation is also a strong influence on air temperature, air and water temperature are closely correlated.

In 2005 at Norris, within 30 minutes of the daily increase in morning air temperature, water temperature at Tantalus Creek displayed a similar rise (figs. 3 and 5). This was followed by an increase in stream flow that lagged behind by less than an hour. The actual air temperature was not a critical parameter, because it is lower than the temperature in the streambed where melting of snow and ice took place. One can envision the temperature of the streambed as balanced by the temperatures of the air, the flowing water and the underlying ground. As shown by the dataset from the Tantalus weir, the creek water is never below freezing temperatures. As such, neither will be the ground in contact with the water. Because the ground temperature generally increases towards the center of the creek, a "buffer zone" of bare ground forms on the banks adjacent to the creek, inside which the ground is sufficiently warmed to prevent both snow from collecting on the surface and the wet soil from freezing (fig. 16). The ground surface in the geyser basin is generally soggy and waterlogged, and this water is subject to the freezing/thawing cycles. Therefore, there is a continuous source of ground water available to the creek via subsurface flow, even 

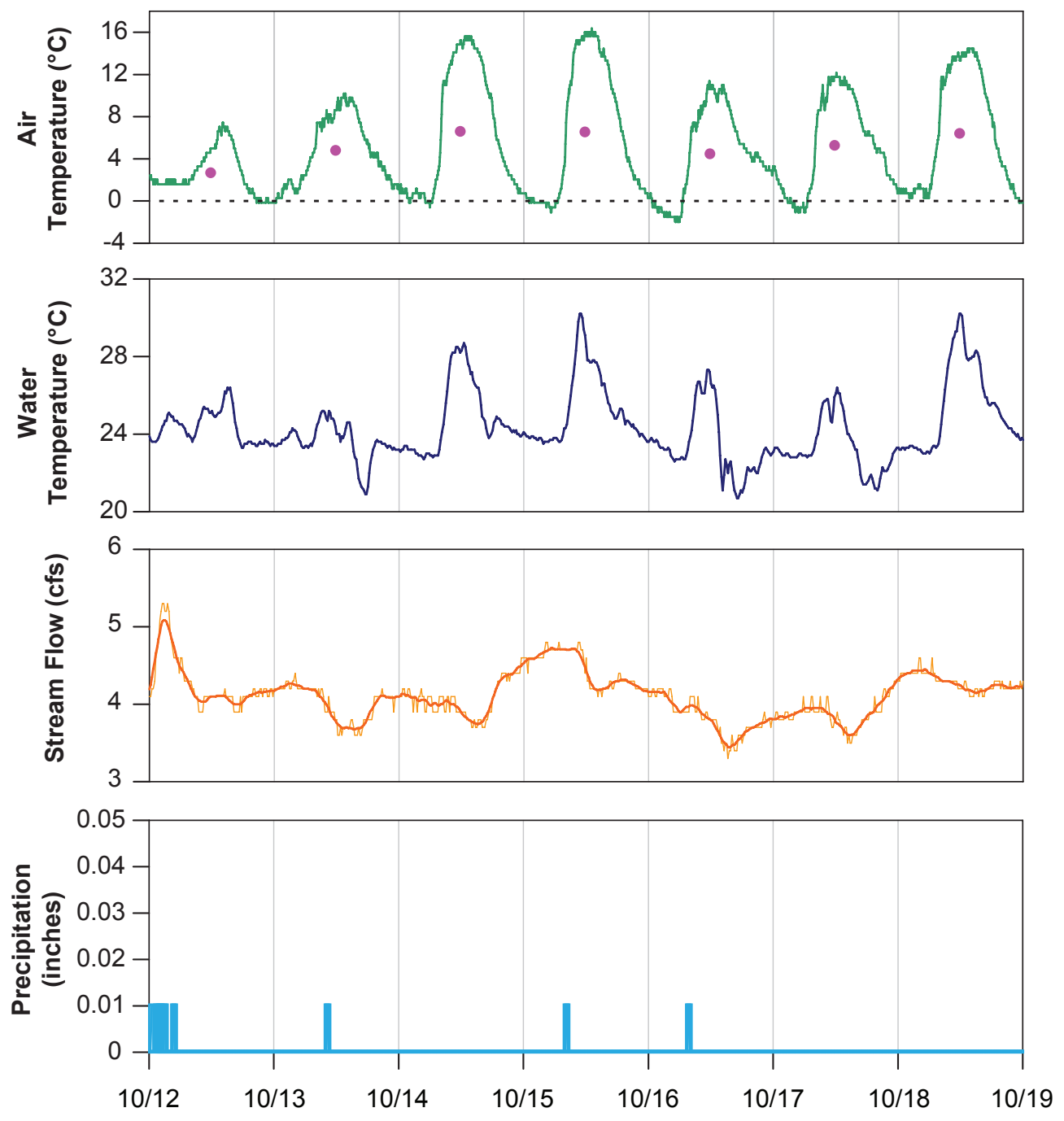

Figure 13. Air temperature, water temperature, stream flow, and precipitation for the week of October 12-19, 2005. Symbols are as in figure 3.

during times without precipitation. There is a constantly shifting balance between the cold winter air that induces snow and ice formation and the heat coming from the ground that causes melting. In the early morning when the air is coldest, melting is inhibited. This represents the low point in stream flow for the day. As the air heats up, the buffer zone grows, moving back from the banks of the creek. This allows for melting of ice and snow adjacent to the creek and increases stream flow. Interestingly, there is no corresponding decrease in water temperature as flow increases. Melting (and hence, flow) tapers off in the latter part of the day as air temperatures fall and the buffer zone shrinks back in toward the creek.

\section{Summertime Behavior}

At the other end of the spectrum, the typical summer-type flow patterns likely reflect evaporation of water from Tantalus
Creek in the afternoon. Tantalus Creek is generally $10-20^{\circ} \mathrm{C}$ warmer than the river it flows into (the Gibbon River), due to the heavy influence of thermal waters (fig. 17). Further, temperature of the water is not measured until it arrives at the weir, by which point it is able to cool significantly by exposure to ambient conditions (Wright and Horrall, 1967). Water from many of Norris' thermal features emerges at $70-90^{\circ} \mathrm{C}$ (Fournier and others, 2002; Ball and others, 2002; Ball and others, 2001; White and others, 1988). The high air temperature and low relative humidity of the summertime afternoons, combined with already elevated water temperatures, could be sufficient to promote evaporation, thereby causing stream flow to decrease. Wright and Horrall (1967) calculated the maximum evaporative heat loss of the Madison River (another thermally-influenced Yellowstone river) to occur at 16:00, when the water-air-vapor pressure gradient and the wind speed were both found to be at their greatest. 

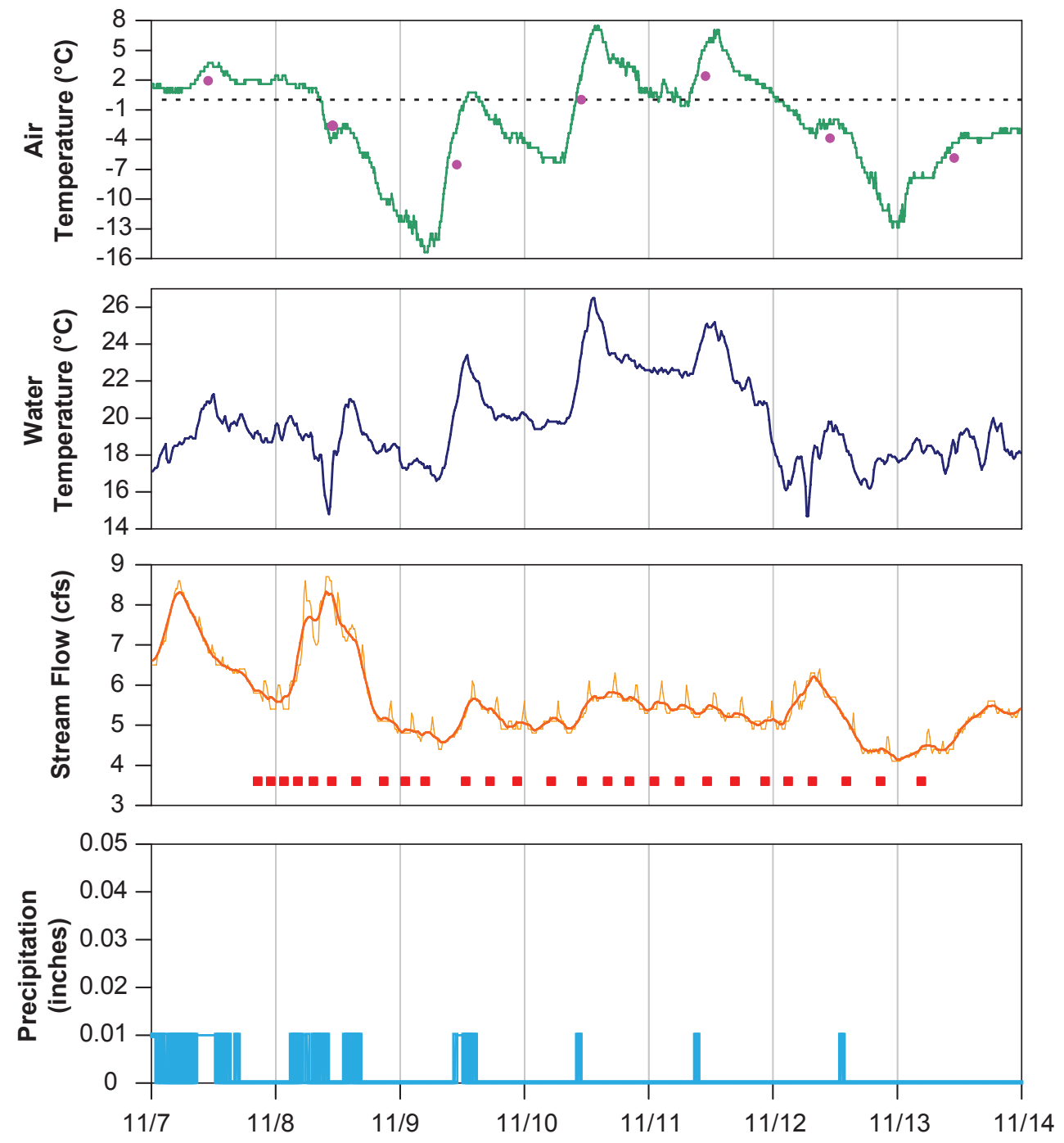

Figure 14. Air temperature, water temperature, stream flow, and precipitation for the week of November 7-14, 2005. Symbols are as in figure 3.

The afternoon drop in the amount of water in the creek is apparently not sufficient to alter the water temperature, which during the day seems to respond to air temperature (and presumably solar radiation more directly). However, when air temperature drops off at night, flow increases concurrently. This perhaps suggests that during the heat of the day, water is lost to evaporation (thereby also removing heat from the water), but when the air cools again in the evening and relative humidity increases, this process ceases. The smaller secondary temperature maximum could be a response to the decrease in evaporation. Because the creek is comprised predominantly of thermal waters (Ball and others, 2002; Norton and others, 1989; Jaworowski and others, 2006), simply a reduction in the amount of evaporative cooling might be sufficient to generate a small rise in water temperature.

Our primary hypothesis to explain the shape of the summer flow curve is that high water and summer air temperatures and the shallowness of Tantalus Creek combine to promote evaporation in the afternoon. Other options include transpiration and/or subsurface recharge. Water loss from the system by transpiration of plants (resulting in the afternoon trough) is ruled out because much of the Norris Geyser Basin is barren (vegetation free) due to the high temperatures, making it unlikely that transpiration is a major factor in Norris Geyser Basin hydrology. Another option could be increased recharge as water temperatures climb in the afternoon, decreasing the viscosity of the stream water and allowing it to sink into the substrate more easily. This might contribute to the overall streamflow dynamics as well; however, the Tantalus typically does not have a porous streambed. Instead, the streambed is mostly silicified and has formed a hardpan-like interface (White and others, 1988), making it improbable that infiltration of water through the streambed into the subsurface is a major factor in the hydrologic behavior. 

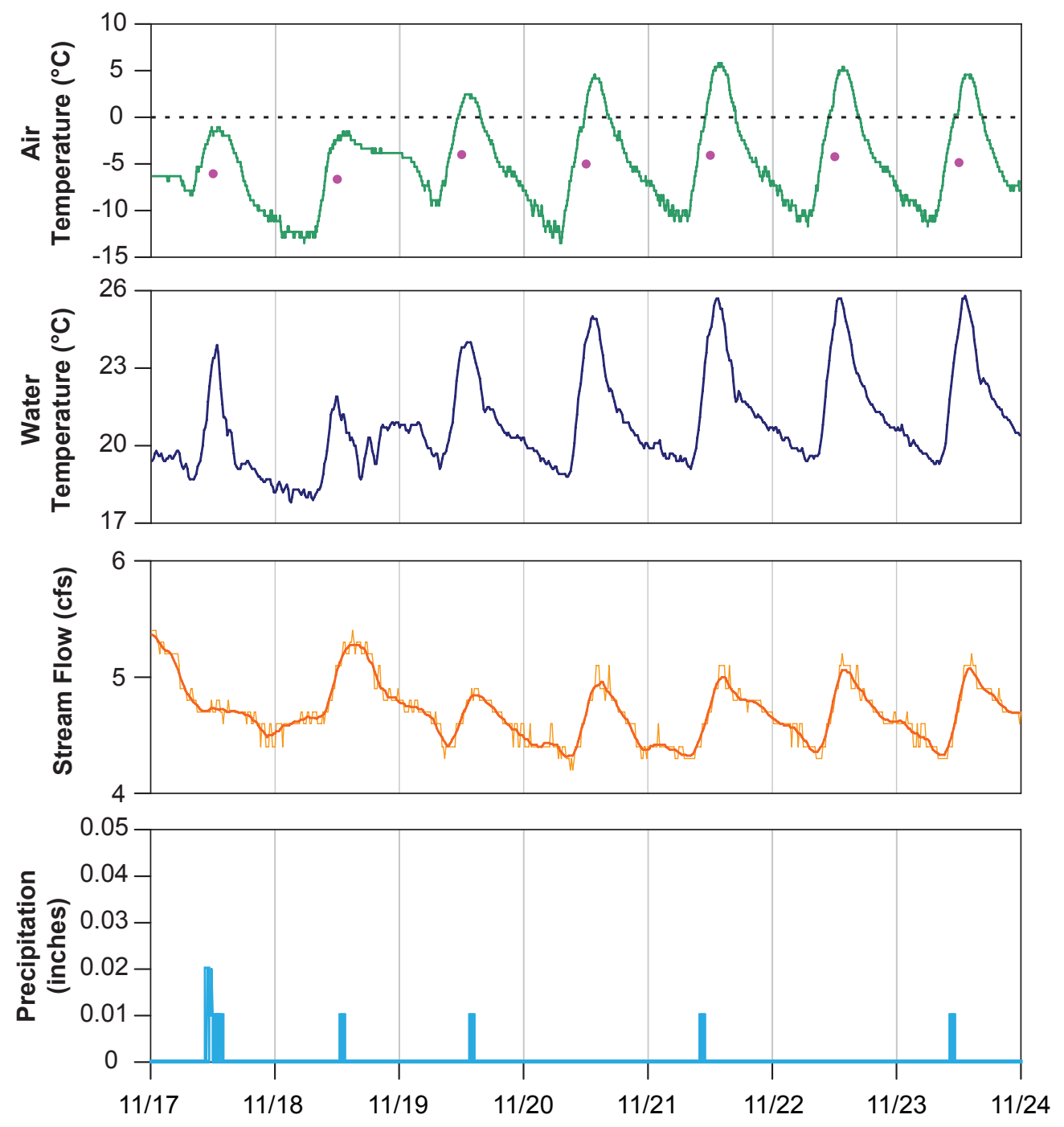

Figure 15. Air temperature, water temperature, stream flow, and precipitation for the week of November 17-24, 2005. Symbols are as in figure 3.

\section{Spring and Autumn Behavior}

Spring and fall are transitional periods between winter and summer and therefore display the characteristics of both endmember behaviors, depending upon the daily average air temperature. When average daily temperatures are consistently below $0^{\circ} \mathrm{C}$, the winter pattern is present. When average temperatures are consistently above $0^{\circ} \mathrm{C}$, the summer pattern emerges. When temperatures hover around freezing, the flow curve becomes very irregular and is frequently without regular diurnal variation. The flow pattern seems to be able to respond very quickly to such changes; even when average temperatures drifted above $0^{\circ} \mathrm{C}$ for just a few days in the spring; for example, the summer-type peaks emerged. This quick response is likely due to the small discharge and resulting shallowness of Tantalus Creek.

\section{Summary}

In 2005, there were two distinct flow patterns of Tantalus Creek throughout the year. The winter pattern represents melting of snow and ice during the warmer afternoon hours, causing stream flow to increase during the day, mirroring the daytime rises of water and air temperature. The summer pattern apparently reflects evaporation during the warmest hours of the day, resulting in an afternoon dip in stream flow that returns to its otherwise steady plateau of values once the air cools. Water temperature may respond in turn to the rising overnight flow pattern with a small increase to a secondary water temperature maximum during the night. Further constraints and verification of these ideas could be gathered by analyzing variations in stream conductivity (both spatial and temporal), taking profiles of soil temperature, assessing 

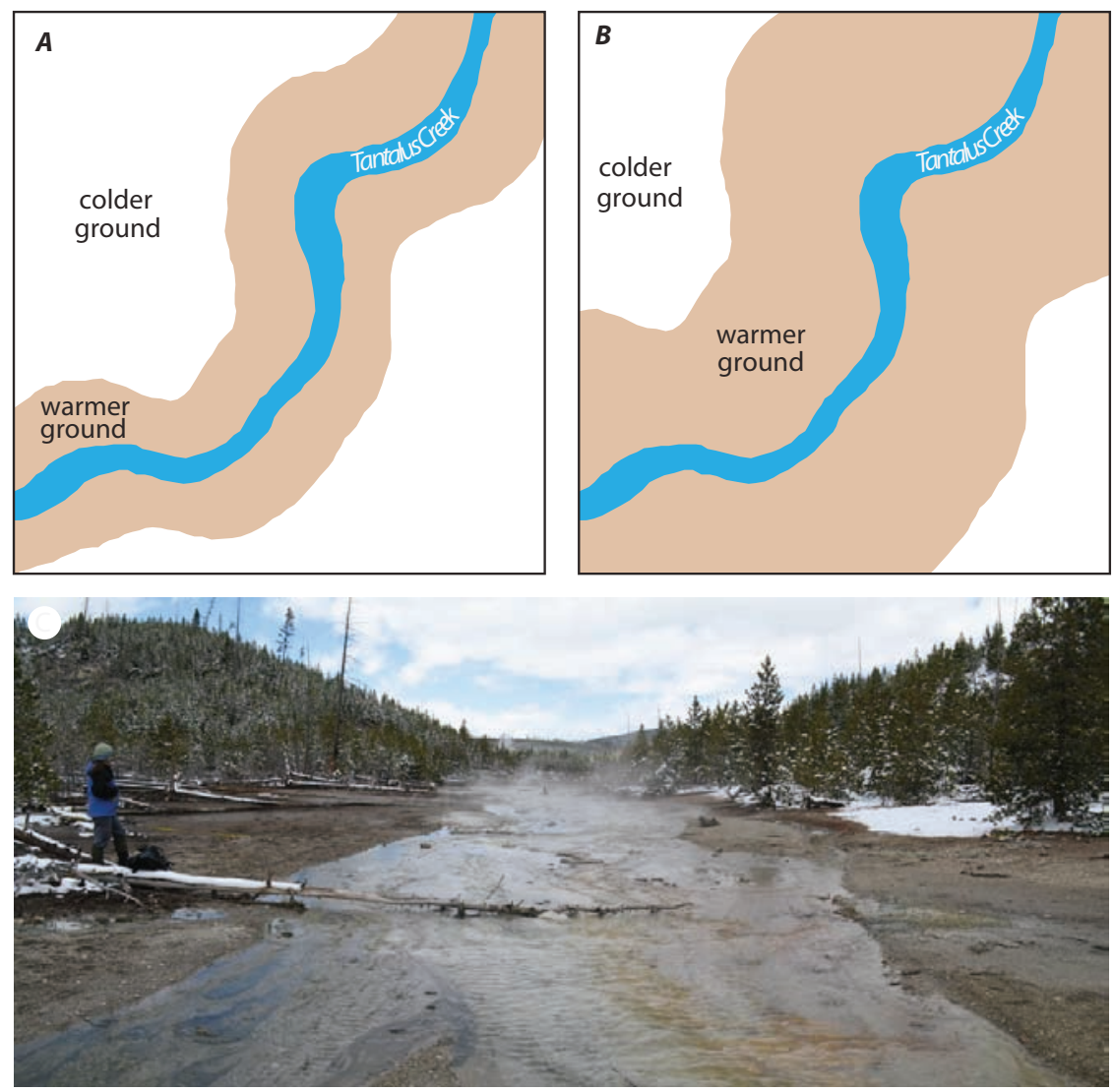

Figure 16. Schematic diagram depicting the response of snow cover, and hence ground temperature, in the vicinity of Tantalus Creek to varying winter air temperatures. Overnight, when air temperatures are low $(A)$, the area of cold ground surrounding the creek expands inward, and ice accumulation is increased (snow would also be allowed to collect closer to the creek, if it were snowing at the time). During the afternoon, when air temperatures are higher $(B)$, melting is favored and the area of bare/warmer ground increases along the banks of the creek. The creek, proximal bare ground and distal snow-covered regions are shown in $(C)$.

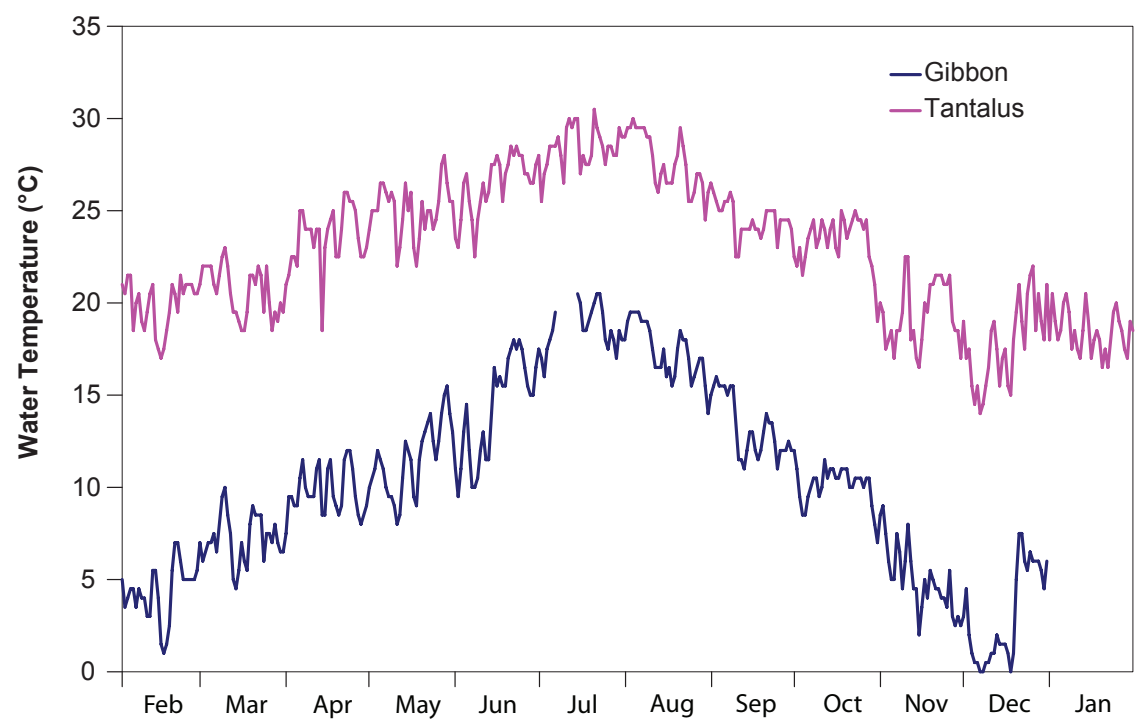

Figure 17. Comparison of water temperatures of Tantalus Creek at the weir and also the Gibbon River at Madison Junction from February 2005 through January 2006. 
the spatial variations in water temperature to supplement the temporal data now available and by collecting realtime data for chloride concentrations and/or conductivity. Simple thermal modeling would also provide important insights. Other overall observations within this report include: 1) stream flow at Tantalus Creek rarely falls below $2 \mathrm{cfs}$ and rarely rises above 5 cfs except during periods of intense rainfall, and 2) discharge from eruptions at Echinus Geyser reach the Tantalus weir in 80 to 90 minutes, implying that the slug of water travels about $0.4 \mathrm{~m} \mathrm{~s}^{-1}$.

\section{Acknowledgments}

We appreciate helpful comments by Deb Bergfeld, Sean Eagan, Shaul Hurwitz, Steve Ingebritsen and Cheryl Jaworowski. NWIS data was provided by Wayne Berkas of the USGS office in Helena, Montana. The manuscript was carefully reviewed by Cindy Werner and Deborah Bergfeld. The Tantalus weir was in part built and maintained by the late Irving Friedman, whose diligence and passion inspired all of us.

\section{References}

Ball, J.W., McCleskey, R.B., Nordstrom, D.K., Holloway, J.M., and Verplanck, P.L., 2002, Water-Chemistry Data for Selected Springs, Geysers, and Streams in Yellowstone National Park, Wyoming, 1999-2000: U.S. Geological Survey Open-File Report 02-382, 103 p.

Ball, J.W., Nordstrom, D.K., McCleskey, R.B., Schoonen, M.A., and $\mathrm{Xu}, \mathrm{Y} ., 2001$, Water-chemistry and on-site sulfurspeciation data for selected springs in Yellowstone National Park, Wyoming, 1996-1998: U.S. Geological Survey OpenFile Report 01-49, 42 p.

Christiansen, R.L., 2001, The Quaternary and Pliocene Yellowstone Plateau volcanic field of Wyoming, Idaho, and Montana: U.S. Geological Survey Professional Paper 729-G, 145 p.

Christiansen, R.L., Lowenstern, J.B., Smith, R.B., Heasler, H., Morgan, L.A., Nathenson, M., Mastin, L.G., Muffler, L.J.P., and Robinson, J.E., 2007, Preliminary Assessment of Volcanic and Hydrothermal Hazards in Yellowstone National Park and Vicinity: U.S. Geological Survey OpenFile Report 2007-1071.

Fournier, R.O., Weltman, U., Counce, D., White, L.D., and Janik, C.J., 2002, Results of weekly chemical and isotopic monitoring of selected springs in Norris Geyser Basin, Yellowstone National Park during June-September, 1995: U.S. Geological Survey Open-File Report 02-344, 50 p.
Friedman, I., in press, Monitoring changes in geothermal activity at Norris Geyser Basin by satellite telemetry, Yellowstone National Park, Wyoming, in Morgan, L.A., ed., Integrated geoscience studies in the Greater Yellowstone area- Volcanic, hydrothermal and tectonic processes in the Yellowstone geoecosystem: U.S. Geological Survey Professional Paper 1717.

Friedman, I. and Norton, D.R., in press, Is Yellowstone losing its steam? Chloride flux out of Yellowstone National Park, in Morgan, L.A., ed., Integrated geoscience studies in the Greater Yellowstone Area-Volcanic, hydrothermal and tectonic processes in the Yellowstone geoecosystem: U.S. Geological Survey Professional Paper 1717.

Hurwitz, S., Lowenstern, J.B., and Heasler, H., 2007, Spatial and temporal geochemical trends in the hydrothermal system of Yellowstone National Park-Inferences from river solute fluxes: Journal of Volcanology and Geothermal Research, doi:10.1016/j.jvolgeores.2007.01.003.

Ingebritsen, S.E., Galloway, D.L., Colvard, E.M., Sorey, M.L., and Mariner, R.H., 2001, Time-variation of hydrothermal discharge at selected sites in the western United StatesImplications for monitoring: Journal of Volcanology and Geothermal Research, v. 111, p. 1-23.

Jaworowski, C., Heasler, H.P., Hardy, C.C., and Queen, L.P., 2006, Control of hydrothermal fluids by natural fractures at Norris Geyser Basin: Yellowstone Science v.14, no. 4.

Norton, D.R., Friedman, I., Mohrman, J., and Hutchinson, R.A., 1989, Monitoring of thermal activity in the northern part of Yellowstone National Park and vicinity-Part 1, February 1985-June 1988: U. S. Geological Survey OpenFile Report 89-0211, 35 p.

White, D.E., Hutchinson, R.A., and Keith T.E.C., 1988, The geology and remarkable thermal activity of Norris Geyser Basin, Yellowstone National Park, Wyoming: U.S. Geological Survey Professional Paper 1456, 84 p.

Wright, J.C., and Horrall, R.M., 1967, Heat budget studies on the Madison River, Yellowstone National Park: Limnology and Oceanography, v. 12, no. 4, p. 578-583. 